\title{
Impact of environmental conditions on biomass yield, quality, and bio-mitigation capacity of Saccharina latissima
}

\author{
Annette Bruhn ${ }^{1, *}$, Ditte Bruunshøj Tørring ${ }^{2}$, Marianne Thomsen ${ }^{3}$, \\ Paula Canal-Vergés ${ }^{2}$, Mette Møller Nielsen ${ }^{1,2}$, Michael Bo Rasmussen ${ }^{1}$, \\ Karin Loft Eybye ${ }^{5}$, Martin Mørk Larsen ${ }^{4}$, Thorsten Johannes Skovbjerg Balsby ${ }^{1}$, \\ Jens Kjerulf Petersen ${ }^{2}$ \\ ${ }^{1}$ Department of Bioscience, Aarhus University, Vejlsøvej 25, 8600 Silkeborg, Denmark \\ ${ }^{2}$ Danish Shellfish Centre, Institute of Aquatic Resources, Technical University of Denmark, DTU-Aqua, Øroddevej 80, \\ 7900 Nykøbing Mors, Denmark \\ ${ }^{3}$ Department of Environmental Sciences, Aarhus University, Frederiksborgvej 399, 4000 Roskilde, Denmark \\ ${ }^{4}$ Department of Bioscience, Aarhus University, Frederiksborgvej 399, 4000 Roskilde, Denmark \\ ${ }^{5}$ Division of Life Science \& Food Technology, Danish Technological Institute, Kongsvang Allé 29, 8000 Aarhus C, Denmark
}

\begin{abstract}
Seaweeds are attractive as a sustainable aquaculture crop for food, feed, bioenergy and biomolecules. Further, the non-value ecosystem services of seaweed cultivation (i.e. nutrient recapture) are gaining interest as an instrument towards sustainable aquaculture and for fulfilling the aims of the EU Marine Strategy Framework Directive. Environmental factors determine the yield and quality of the cultivated seaweed biomass and, in return, the seaweed aquaculture affects the marine environment by nutrient assimilation. Consequently, site selection is critical for obtaining optimal biomass yield and quality and for successful bio-mitigation. In this study, 5 sites for cultivation of Saccharina latissima were selected within a eutrophic water body to guide site selection for future kelp cultivation activities. Results were coupled to marine monitoring data to explore the relationship between environmental conditions and cultivation success. The biomass yields fluctuated 10-fold between sites due to local variations in light and nutrient availability. Yields were generally low, i.e. up to $510 \mathrm{~g}$ fresh weight (FW) per meter seeded line; however, the dry matter contents of protein and high-value pigments were high (up to $17 \%$ protein and $0.1 \%$ fucoxanthin). Growth performance, biomass quality and bio-mitigation potential was restricted by low availability of light and bioavailable phosphorus, and biofouling through juvenile suspension feeders was a critical factor at all cultivation sites. At specific sites, the tissue metal contents $(\mathrm{Pb}$ and $\mathrm{Hg}$ ) exceeded the limit values for feed or food. Our results emphasize the importance of careful site selection before establishing large-scale cultivation, and stress the challenges and benefits of kelp cultivation in eutrophic waters.
\end{abstract}

KEY WORDS: Eutrophication $\cdot$ Limfjorden $\cdot$ Seaweed farming $\cdot$ Metals $\cdot$ Nitrogen $\cdot$ Phosphorus Site quality $\cdot$ Ecosystem service

\section{INTRODUCTION}

Cultivation of macroalgae is a rapidly growing industry in a global perspective (FAO 2016). The main driver is the establishment of a production of marine-

${ }^{*}$ Corresponding author: anbr@bios.au.dk

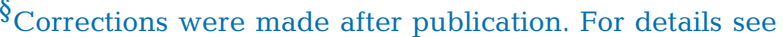
www.int-res.com/articles/aei2017/9/q009p019.pdf This version: January 23, 2017 based biomass for food, energy, protein and biomolecules (Bruton et al. 2009, Kraan 2013, Wei et al. 2013), but also exploitation of the bio-mitigation capacity of the algae is in focus (Troell et al. 1999, Castine et al. 2013, Marinho et al. 2015a). The non-use value eco-

(C) The authors 2016. Open Access under Creative Commons by Attribution Licence. Use, distribution and reproduction are unrestricted. Authors and original publication must be credited. 
system service (Daly 1998) provided by cultivated algae in terms of recapturing nutrients in coastal areas is of commercial and societal interest - as compensation for increased aquaculture activities (Sanderson et al. 2012, Handå et al. 2013, Smale et al. 2013, Holdt \& Edwards 2014, Marinho et al. 2015a) or as a potential instrument for circular nutrient management, improving the ecological status of eutrophic marine areas (Seghetta et al. 2016) in line with the EU Marine Strategy Framework Directive (EU 2008a, 2014).

In Europe, the effort concerning cultivation of large brown algae (Laminariales), in particular, is increasing. The most commonly cultivated brown algae species in Europe, Saccharina latissima ((Linnaeus) C.E. Lane, C. Mayes, Druehl \& G.W. Saunders), has been cultivated on a smaller or larger scale in Ireland, Scotland, Germany, Holland, Spain, Norway, Faroe Islands and Denmark (i.e. Buck \& Buchholz 2004, 2005, Buck et al. 2008, Werner et al. 2009, Wegeberg 2010, Edwards \& Watson 2011, Forbord et al. 2012, Handå et al. 2013, Peteiro \& Freire 2013b, Wegeberg et al. 2013, Marinho et al. 2015a). The achieved biomass yields and the biochemical composition of the biomass vary considerably seasonally and spatially, primarily because of different environmental conditions (Edwards \& Watson 2011, Handå et al. 2013, Peteiro \& Freire 2013a,b, Marinho et al. 2015a). In return, the algae production also exerts an impact on the environmental conditions through the removal of nutrients (Troell et al. 1999, Stephens et al. 2014, Marinho et al. 2015a). Thus, algae cultivation sites should be carefully selected for optimizing biomass production, biomass quality as well as the non-value ecosystem services (Kerrison et al. 2015). Further, the seasonal timing of the deployment and harvest of the algae needs to be optimized according to local environmental conditions. The focus of the optimization, i.e. high protein yield or high carbohydrate yield, will depend on the final application of the biomass. Sporophytes of Laminaria species store nutrients for length growth during periods when environmental nutrients concentrations are high (Bartsch et al. 2008). Thus, high environmental nutrient concentrations favour high tissue nitrogen $(\mathrm{N})$ concentrations: in wild S. latissima up to $3.5 \% \mathrm{~N}$ of dry matter (DM) (Gevaert et al. 2001, Nielsen et al. 2014), up to 5.0\% $\mathrm{N}$ of DM when cultivated in close proximity to fish aquaculture (Handå et al. 2013, Marinho et al. 2015a) and even up to $6.7 \% \mathrm{~N}$ of DM when cultivated under highly eutrophic conditions (Nielsen 2015). The molar N:phosphorus (P) ratio is commonly in the range of 9-25:1 (Atkinson \& Smith 1983), and P con- centrations of up to $0.8 \%$ of DM are reported in nutrient-rich waters (Marinho et al. 2015a). High tissue N concentrations reflect a correspondingly high content of proteins (Manns et al. 2014, Marinho et al. 2015b, Angell et al. 2016). Consequently, both the biomass quality and the bio-mitigation capacity of the produced algae increase in nutrient-rich waters, increasing the value of the biomass, as well as improving the environmental condition of the water body through harvest, and thus removal of nutrients.

Of the 21 Danish water bodies, Limfjorden receives the highest annual net supply of nutrients $(8.2 \mathrm{t} \mathrm{N}$ and $0.30 \mathrm{t} \mathrm{P} \mathrm{km}^{-2} \mathrm{y}^{-1}$; Seghetta et al. 2016). These high nutrient loadings have caused a regime shift in the fjord from benthic to pelagic primary production (KrauseJensen et al. 2012). The high pelagic primary production supports a substantial stock of benthic suspension feeders, including blue mussels Mytilus edulis L., supporting a local mussel fishery (Maar et al. 2010, Timmermann et al. 2014). Mussel farming has been successfully tested as an instrument to recapture nutrients and improve the ecological status of Limfjorden (Petersen et al. 2014), and farming of long-line blue mussels is an emerging business in Limfjorden. Along with the development of the mussel farming industry, interest in macroalgae cultivation is increasing, partly because the 2 crops may be cultivated using the same structures (Nielsen 2015). Due to the high environmental nutrient concentrations, cultivation of large brown algae in a water body like Limfjorden would theoretically hold a potential for the production of a Saccharina biomass with high protein content, representing a higher value for the food or feed market. At the same time the potential of seaweed cultivation as an instrument for circular nutrient management would be maximized. Despite the relatively small size of Limfjorden $\left(1500 \mathrm{~km}^{2}\right)$, local environmental conditions differ considerably between the different basins (Maar et al. 2010). Cultivation of S. latissima has to date been documented only once at 1 site in Limfjorden, indicating a potential for cultivation of $S$. latissima. This study, however, also demonstrates the need for investigating optimal timing of cultivation and harvest in order to maximize biomass yield and avoid biofouling (Wegeberg 2010).

Testing and evaluating the interactions between local environmental conditions and biomass yield, quality and potential for bio-mitigation through nutrient recapture of cultivated kelps in coastal waters is needed before implementing cultivation on a larger scale. This applies not only to Limfjorden, but to any water body where macroalgae cultivation is intended. 
The aim of this study was to compare the biomass yield, bio-mitigation capacity and nutritional quality for food and feed of $S$. latissima cultivated at 5 sites in Limfjorden as well as to explore the influence of local environmental conditions on these parameters with the purpose of guiding site selection and timing of harvest. The 5 selected cultivation sites each represented their basin in Limfjorden, with the basins characterized by different environmental conditions regarding salinity, turbidity, nutrient availability and sediment metal concentrations.

\section{MATERIALS AND METHODS}

\section{Study area and cultivation sites}

Limfjorden is a shallow, semi-enclosed estuary located between the North Sea and the Kattegat (Fig. 1). The total surface area of the fjord is $\sim 1500 \mathrm{~km}^{2}$ and the average depth is $4.6 \mathrm{~m}$. The total catch-

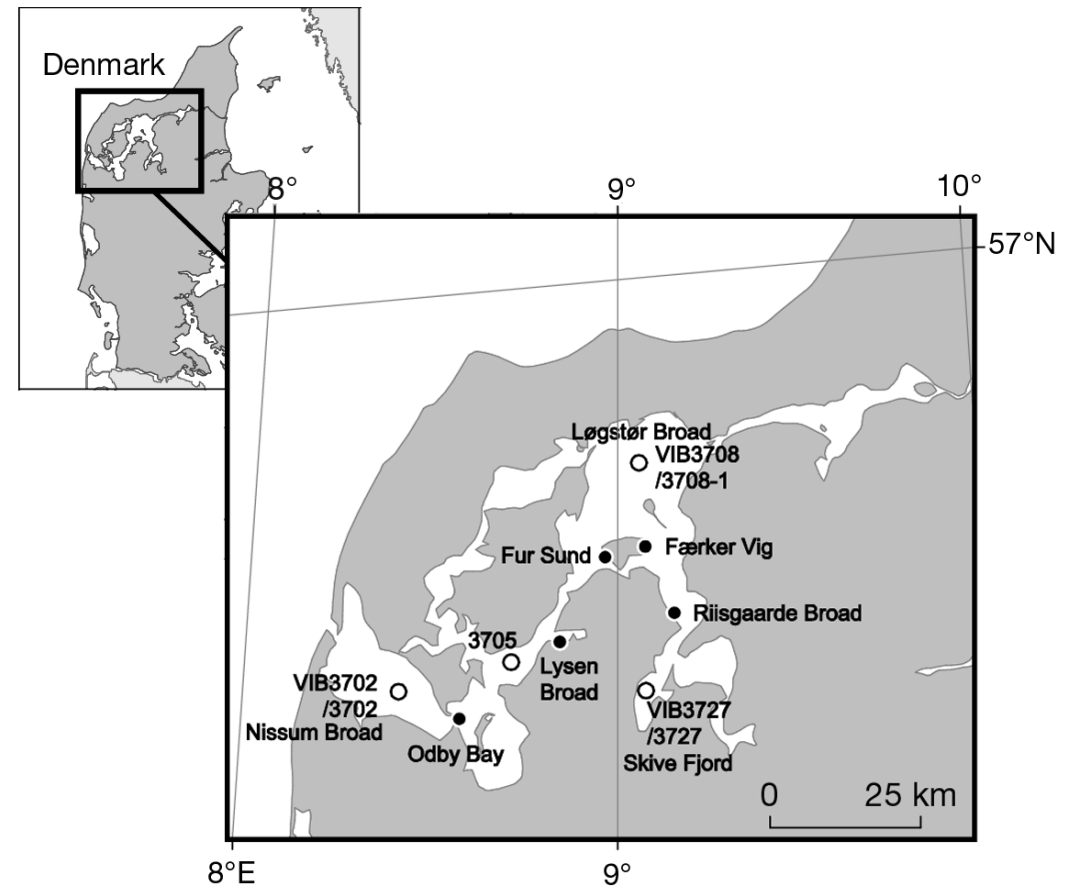

Fig. 1. Location of Limfjorden in Denmark and the 5 Saccharina latissima cultivation sites (filled circles) and 4 environmental monitoring stations (open circles). Stns VIB3702, VIB3708 and VIB 3727 are pelagic stations for monitoring water quality. Stns 3702, 3705, 3708-1 and 3727 are stations for monitoring benthic metal concentrations ment area is $7587 \mathrm{~km}^{2}$ and is predominantly agricultural land. Despite a small tidal amplitude, tidal forces and wind are the drivers of the annual net flow of $6.8 \mathrm{~km}^{3}$ of water from the North Sea via the Thyborøn channel in the west through Limfjorden to the Kattegat. Limfjorden consists of several relatively shallow water basins connected by narrow and deep sounds. The big broads have water depths of 5-8 $\mathrm{m}$, whereas the sounds have depths of 18-22 $\mathrm{m}$, the deepest point being Oddesund $(28 \mathrm{~m})$. The average salinity varies from $32-34$ in the western part to 19-25 in the central and eastern part (Lyngby et al. 1999, Markager et al. 2006, KrauseJensen et al. 2012, Timmermann et al. 2014).

Five existing mussel farms were selected as experimental cultivation sites (Fig. 1, Table 1) for the

following reasons: (1) they were each located in a distinct basin of Limfjorden; (2) aquaculture licenses were already active; (3) the mussel cultivation structures could be used for the seaweed cultivation; and (4) the 5 basins were covered by the Danish National Monitoring and Assessment Program for the Aquatic and Terrestrial Environment (NOVANA).

\section{Environmental data}

For each of the 5 cultivation sites, the data on biomass yield and quality were coupled to environmental data from an environmental monitoring station located centrally within each basin (Fig. 1, Table 2).

Table 1. Location, size and characteristics of the 5 Saccharina latissima cultivation sites in Limfjorden, Denmark. N: north, E: east, S: south, W: west

\begin{tabular}{|lcclcccc|}
\hline Site & \multicolumn{2}{c}{ Position } & Basin & $\begin{array}{c}\text { Size } \\
(\mathrm{m} \times \mathrm{m})\end{array}$ & $\begin{array}{c}\text { Depth } \\
(\mathrm{m})\end{array}$ & $\begin{array}{c}\text { Sea bed } \\
\text { classification }\end{array}$ & Degree of exposure \\
\cline { 2 - 6 } & $\begin{array}{c}\text { Latitude } \\
\left({ }^{\circ} \mathrm{N}\right)\end{array}$ & $\begin{array}{c}\text { Longitude } \\
\left({ }^{\circ} \mathrm{E}\right)\end{array}$ & & & & & \\
\hline Odby Bay & 56.577 & 8.570 & Nissum/Kaas Broad & $300 \times 300$ & 4 & Soft mud & Exposed to winds from E and S \\
$\begin{array}{l}\text { Lysen Broad } \\
\text { Fur Sund }\end{array}$ & 56.692 & 8.841 & Sallingsund & $250 \times 500$ & $2-5$ & Fine sand with clay & Protected \\
Færker Vig & 56.816 & 8.968 & Fur Sund & $250 \times 750$ & 5 & Rocky/sandy & Exposed to strong currents \\
$\begin{array}{l}\text { Riisgaarde } \\
\text { Broad }\end{array}$ & 56.734 & 9.073 & Løgstør Broad & $300 \times 300$ & 4 & Hard sand/stone & Protected \\
Soft mud & Exposed to winds from N, E, S \\
\end{tabular}


Table 2. Deployment and sampling dates at the 5 Saccharina latissima cultivation sites in Limfjorden, batches of seeded lines, as well as identification numbers of and distance to the environmental monitoring stations (pelagic and sediment stations, see Fig. 1) from which data were used for analyses

\begin{tabular}{|c|c|c|c|c|c|c|c|}
\hline Site & $\begin{array}{l}\text { Deployment } \\
\text { date }\end{array}$ & $\begin{array}{c}\text { Sampling } 1 \\
\text { date }\end{array}$ & $\begin{array}{c}\text { Sampling } 2 \\
\text { date }\end{array}$ & Batch & $\begin{array}{l}\text { Pelagic } \\
\text { station }\end{array}$ & $\begin{array}{l}\text { Sediment } \\
\text { station }\end{array}$ & $\begin{array}{l}\text { Distance } \\
(\mathrm{km})\end{array}$ \\
\hline Odby Bay & Dec 6, 2011 & Apr 11, 2012 & Jun 12, 2012 & 1 & VIB3702 & 3702 & 14 \\
\hline Lysen Broad & Dec 6, 2011 & Apr 11, 2012 & Jun 12, 2012 & 1 & $-{ }^{\mathrm{a}}$ & 3705 & 8.5 \\
\hline Fur Sund & Dec 6, 2011 & Apr 11, 2012 & Jun 12, 2012 & 1 & VIB3708 & $3708-1$ & 20 \\
\hline Færker Vig & Oct 28, 2011 & Apr 11, 2012 & May 25, 2012 & 2 & VIB3708 & $3708-1$ & 14 \\
\hline Riisgarde Broad & Dec 6, 2011 & Apr 11, 2012 & Jun 12, 2012 & 1 & VIB3727 & 3727 & 14 \\
\hline
\end{tabular}

Data from the monitoring stations were retrieved from NOVANA through the National Database for Marine Data (ODAM) (Fig. 1, Table 1).

Data on water temperature, salinity, turbidity and concentrations of oxygen, chlorophyll a (chl a), inorganic nutrients (dissolved inorganic $\mathrm{N}$ [DIN = $\left.\mathrm{NO}_{2}{ }^{-}-\mathrm{N}, \mathrm{NO}_{3}{ }^{-}-\mathrm{N}, \mathrm{NH}_{4}{ }^{+}-\mathrm{N}\right]$, dissolved inorganic bioavailable $\mathrm{P}$ [ortho-P]) and sediment metals were collected and analysed using standard methods according to the current national Technical Instructions for Marine Monitoring (Markager 2004, Pedersen et al. 2004, Larsen 2013, Markager \& Fossing 2013, Vang 2013, Vang \& Hansen 2013). Sampling was performed on average every 2-3 wk. Sampling of sediment was performed every 1-5 yr. By trapezoidal integration, all pelagic environmental data were calculated into weighted averages over 2 periods up to the time point of each biomass sampling-early spring: the period of detectable growth from 1 February 2012 to Sampling 1, 11 April 2012; and late spring: the last part of the grow-out period from Sampling 1 (11 April 2012) to Sampling 2 (25 May or 12 June 2012) (see next section and Table 2).

Data regarding temperature, salinity and turbidity were differentiated according to the actual cultivation depths (1.5 and $2.5 \mathrm{~m}$, respectively). Data regarding nutrients, oxygen and chl a were only available from $1 \mathrm{~m}$ of depth, but no significant stratification prevailed during the cultivation period. Sediment metal concentration data were averaged for each station over a period covering the preceding $10 \mathrm{yr}$ (2003-2012). Data on local incoming light was supplied from the Danish Meteorological Institute.

Ideally, cultivation sites and monitoring stations could have been geographically closer. However, the data from the environmental monitoring stations was considered as being representative for the cultivation sites despite the distances of $8-20 \mathrm{~km}$ between monitoring station and cultivation site for a number of reasons: (1) other studies correlating monitoring data and macrovegetation performance in Limfjorden generally achieve good correlations (e.g. KrauseJensen et al. 2012), (2) the experimental period from winter to early summer is a period of maximal winddriven circulation (Wiles et al. 2006), and absence of vertical stratification (Christiansen et al. 2006), (3) mixing was confirmed as no stratification was observed during the experimental period, and (4) sites and stations were located in the more open parts of the basins in proximity to point sources of run-off from land. Coupling of biomass yield and quality to environmental data for the cultivation site at Lysen Broad was not possible, as only data on sediment chemistry was available from the environmental monitoring station in this basin.

\section{Cultivation and sampling of Saccharina latissima}

Two batches of $S$. latissima seeded lines were used in the cultivation experiment (Table 2). Batch 1 consisted of $500 \mathrm{~m}$ of ready-made seeded line (diameter: $6 \mathrm{~mm}$ ) produced by direct sporulation (Wegeberg 2010) at Blue Food A/S, Denmark. This batch was delivered to the Danish Shellfish Centre on 5 December 2011, kept in running seawater overnight and deployed the following day at 4 sites: Odby Bay, Lysen Broad, Fur Sund and Riisgaarde Broad. Batch 2 was deployed at Færker Vig and consisted of $125 \mathrm{~m}$ of seeded line (diameter: $6 \mathrm{~mm}$ ), also produced through direct sporulation, but at the Danish Shellfish Centre during August 2011. Both batches were produced from fertile material from a $S$. latissima population in the Danish Belt Sea, and visual inspection of the lines upon deployment did not reveal any difference between the 2 batches in quality, density or size of the juvenile sporophytes. Length of the seedlings at deployment was $\sim 1 \mathrm{~mm}$. All lines were 
deployed as vertical droppers, each $2.5 \mathrm{~m}$ long, attached to a horizontal long-line with a $50 \mathrm{~cm}$ tethering line. The droppers were interspaced by $40 \mathrm{~cm}$ along the horizontal long-line. During the grow-out period, the horizontal long-lines were kept $50 \mathrm{~cm}$ below the water surface to avoid disturbance by floating ice and heavy storms. Consequently, the seeded lines were positioned between 1 and $3.5 \mathrm{~m}$ depth.

Sampling of biomass was performed twice by random selection of 3 droppers from each site: Sampling 1 on 11 April 2012 and Sampling 2 on either 25 May or 12 June 2012 (Table 2). The lines were brought to the laboratory where the upper $2 \mathrm{~m}$ of each line was divided into 2 sections: the upper section represented the seeded line hanging in 1-2 $\mathrm{m}$ depth (average $1.5 \mathrm{~m}$ ), and the lower section representing the seeded line hanging at a depth of 2-3 m (average $2.5 \mathrm{~m}$ ). The remaining $50 \mathrm{~cm}$ of each seeded line with the attached bottom weight was discarded due to lack of biomass. The following parameters were recorded for both sections of the lines: total weight of sample (seeded line + algae + epiphytes), weight of seeded line, weight of algae, weight and taxonomy of dominating biofouling epiphytic organisms, and finally, average sporophyte frond length, based on 15 randomly selected sporophytes. After sampling, tissue samples were stored at $-20^{\circ} \mathrm{C}$ until biochemical analyses were performed. Due to increasingly heavy biofouling by epiphytic organisms over time, algae material harvested from late May and onwards (Sampling 2) was fully covered with epiphytic organisms such as ascidians and juvenile mussels, and thus considered unsuitable for food or feed applications. Therefore only algae material sampled in April (Sampling 1) was used in the biochemical analyses. Due to very limited biomass harvested from Fur Sund at $2.5 \mathrm{~m}$ in April, only pigment analyses were performed on this biomass.

\section{Calculations of growth rates and biomass yields}

Specific growth rates (SGRs) were calculated from measurements of the fresh weight (FW) per running meter of seeded line as:

$$
\operatorname{SGR}(\%)=100 \times \frac{\ln \left(\frac{F_{t}}{F W_{0}}\right)}{t}
$$

where $\mathrm{FW}_{0}$ and $\mathrm{FW}_{t}$ corresponded to the fresh weight of $S$. latissima per $m$ of seeded line at time 0 and after $t$ days of cultivation, respectively. Biomass yields were reported as $\mathrm{g} F W$ per $\mathrm{m}$ of seeded line $(\mathrm{g}$
$\mathrm{FW} \mathrm{m}^{-1}$ ). The average frond length of the S. latissima sporophytes was calculated as an average length \pm $\mathrm{SE}$ of the 15 randomly selected sporophytes from each sample.

\section{Saccharina latissima tissue biochemistry}

DM, ash, carbon (C), N and P. Algae samples were freeze-dried at $-40^{\circ} \mathrm{C}$ and homogenized by dry milling. DM content was calculated as percentage of FW. A known amount of dry algae was combusted at $550^{\circ} \mathrm{C}$ for $2 \mathrm{~h}$, and the ash fraction was calculated as percentage of DM. Concentrations of $\mathrm{C}$ and $\mathrm{N}$ in the freeze-dried algae tissue were analysed by PreglDumas ignition in pure oxygen atmosphere followed by chromatographic separation of $\mathrm{C}$ and $\mathrm{N}$ with detection of the individual elements by thermal conductivity (Culmo 2010). Total P content of the algae biomass was as analysed spectrophotometrically according to standard methods (Grasshoff et al. 1983). Prior to analysis, the dried and homogenized samples were heated at $550^{\circ} \mathrm{C}$ for $2 \mathrm{~h}$, autoclaved with $2 \mathrm{M}$ hydrogen chloride ( $\mathrm{HCl})(20 \mathrm{mg} \mathrm{DM}$ for $7 \mathrm{ml}$ acid), and finally filtered through GFF filters (Whatman).

Metals. Metal concentrations ( $\mathrm{As}, \mathrm{Cd}, \mathrm{Hg}, \mathrm{Pb}$ ) were determined by inductively coupled plasma-mass Spectrometry (ICP-MS). In short, a $0.2 \mathrm{~g}$ dry subsample was digested in a closed vessel microwave oven using $5 \mathrm{ml}$ of nitric acid $(7 \mathrm{M})$ and $1 \mathrm{ml}$ of hydrogen peroxide, then diluted to $50 \mathrm{ml}$ with milliQ water, followed by ICP-MS determination using internal standards of $\mathrm{Rh}$, Ir and Ge to correct for drift (see Nielsen et al. 2012). Certified reference material of macroalgae from IAEA-140 (Coquery et al. 2000) was used for quality assurance.

Pigments. Pigment concentrations (chl $a$, fucoxanthin, violaxanthin and $\beta$-carotene) were determined using acetone extraction and quantification by HPLC as described in Boderskov et al. (2016). Pigment standards were obtained from DHI Laboratory Products.

Crude protein and amino acids (AAs). Crude protein and AA composition were analysed only for samples from Færker Vig. Total organic bound crude protein was determined by the Kjeldahl principle according to Nordic Committee on Food Analysis (2005). Protein content was calculated by multiplying the amount of $\mathrm{N}$ by a factor of 5 and expressed as percent of DM (Angell et al. 2016). The determination of AAs was done by HPLC according to EU 152/2009 (A) and ISO 13903:2005. AA contents were expressed as percentage of DM. 


\section{Data analysis}

For comparing growth performance and biomass quality between sites and depths, 2-way ANOVA (using Tukey's post hoc analysis) and linear regression analyses were performed using JMP 10.0 (SAS Institute). Explorative data analysis was performed to identify significant correlation patterns between macroalgae growth and environmental parameters. Data were log transformed in order to obtain normal distribution and homogeneity of variance for the residuals of the models. Multivariate data analysis (MVDA) was performed to guide model selection of variables to be tested using general linear models (GLM). Partial least square regression (PLS-R) was used as explorative technique for pattern recognition using the Unscrambler v.10.2 (CAMO Software). Biomass yield and biofouling in early and late spring as well as bio-mitigation capacity, i.e. $\mathrm{N}$ and $\mathrm{P}$ content in the harvested seaweed biomass, were selected as Y-variables in the PLS-R models and modelled using environmental parameters, characterising the marine growth environment surrounding the individual cultivation sites, as original explanatory variables (data not shown). GLMs were used to assess the effect of light, salinity, availability of ortho-P, temperature and environmental N:P ratio (NP_E) on growth performance, biofouling, and biomass quality. The environmental parameters were selected as independent variables based on the indicative impact on the dependent variable (biomass growth parameters and quality), as observed from MVDA (data not shown). As several of the independent variables showed strong correlations (Pearson, Table S1 in the Supplement at www.int-res.com/articles/suppl/q008 p619_supp.pdf), the independent variables were split into 2 models to avoid issues with collinearityModel 1: light, salinity, and ortho-P; Model 2: temperature, salinity and NP_E. These analyses were performed in SAS 9.3 (SAS Institute) using the Proc mixed function with cultivation site as a random factor. The level of significance applied was 0.05 , unless mentioned otherwise.

\section{RESULTS}

\section{Environmental conditions}

The environmental conditions differed among the basins of Limfjorden (Fig. 2, Table 1). Differences were most pronounced with regard to salinity, light, and concentrations of inorganic nutrients and chl $a$.

\section{Salinity}

The salinity in the different basins decreased with increasing distance from the North Sea: Nissum Broad, 29.0-31.9; Løgstør Broad, 26.0-28.9; and Skive Fjord, 23.5-26.5. In Nissum Broad, the salinity increased slightly over the grow-out period, whereas in Løgstør Broad and Skive Fjord the salinity decreased over the period, reflecting a stronger influence of run-off from land (Fig. 2A). No pronounced stratification of the water column was observed from the monitoring data during the grow-out period at any of the stations (data not shown).

\section{Temperature}

Generally, the differences in temperature among stations were minor $\left(<1^{\circ} \mathrm{C}\right)$, and even less between the 2 cultivation depths at any station. The temperatures experienced during the full grow-out period ranged from minimum temperatures in all basins measured on 1 February (between -0.2 and $1.5^{\circ} \mathrm{C}$ ) to maximum temperatures in June $\left(13.8-14.1^{\circ} \mathrm{C}\right)$ (Fig. 2B).

\section{Inorganic nutrients}

The average concentrations of DIN from deployment to April ranged between 20 and $40 \mu \mathrm{M}_{i}$ however, with concentrations up to $58 \mu \mathrm{M}$ in Skive Fjord in winter and early spring (Fig. 2C). In late spring, between April and June, the DIN concentrations decreased $<2 \mu \mathrm{M}$ in Nissum Broad, but remained high between 10 and $20 \mu \mathrm{M}$ in the other basins. In all periods, the highest DIN concentrations were measured near Skive Fjord and the lowest in Nissum Broad. Concentrations of ortho-P were high during the winter period $(0.4-0.9 \mu \mathrm{M})$, but decreased below $0.1 \mu \mathrm{M}$ during the spring bloom from February to April (Fig. 2D).

\section{Pelagic chl a}

In early spring, February and March, the phytoplankton concentrations peaked with 12 and $16 \mu \mathrm{g}$ chl a $\mathrm{l}^{-1}$ in Løgstør and Nissum Broad, respectively (Fig. 2E). In Skive Fjord, the highest chl a concentrations were measured in early June $\left(14 \mu \mathrm{g} \mathrm{chl} \mathrm{a} \mathrm{l}^{-1}\right)$.

\section{Light}

The photon flux density generally decreased by $\sim 50 \%$ from 1.5 to $2.5 \mathrm{~m}$, emphasizing the high turbidity of Limfjorden (Fig. 2F). The algae at $1.5 \mathrm{~m}$ experienced an average of $400-700 \mu \mathrm{mol}$ photons $\mathrm{m}^{-2} \mathrm{~s}^{-1}$ in late 


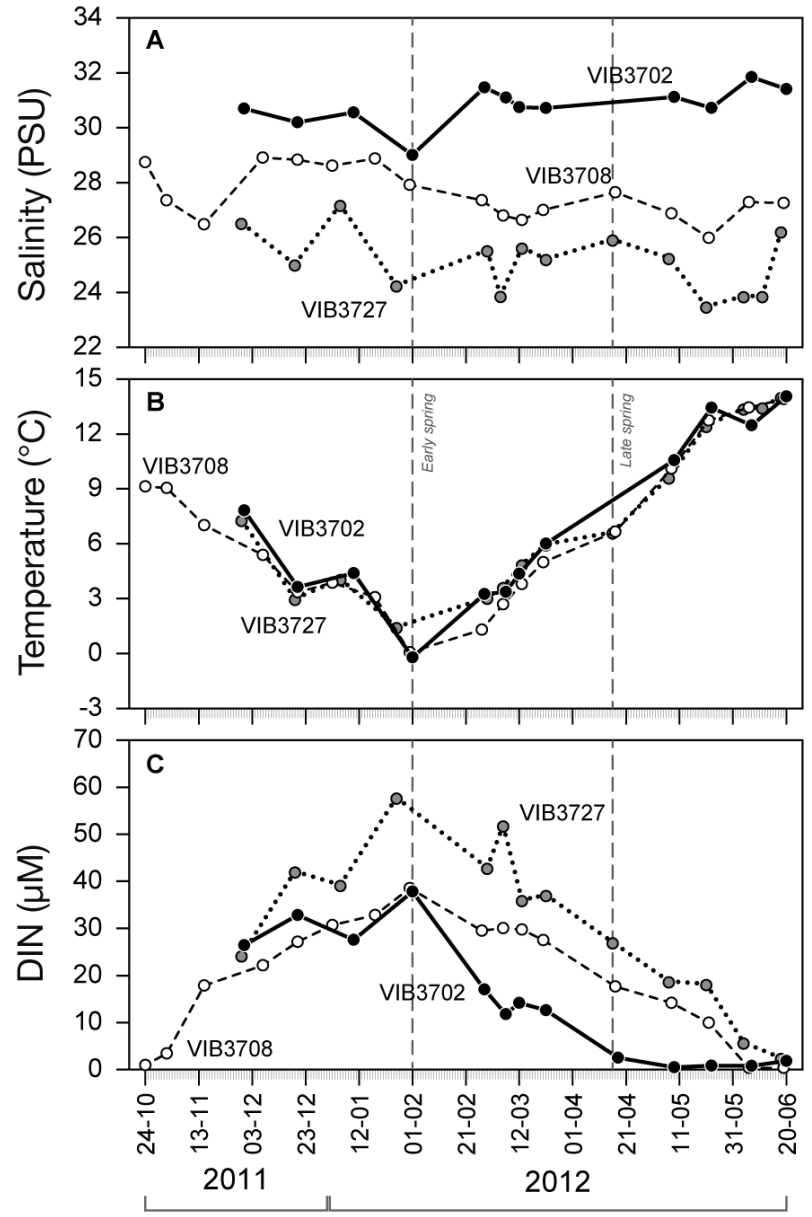

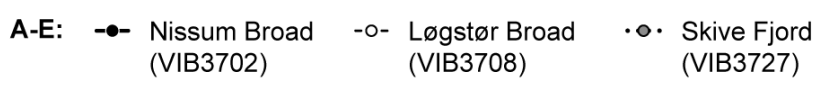

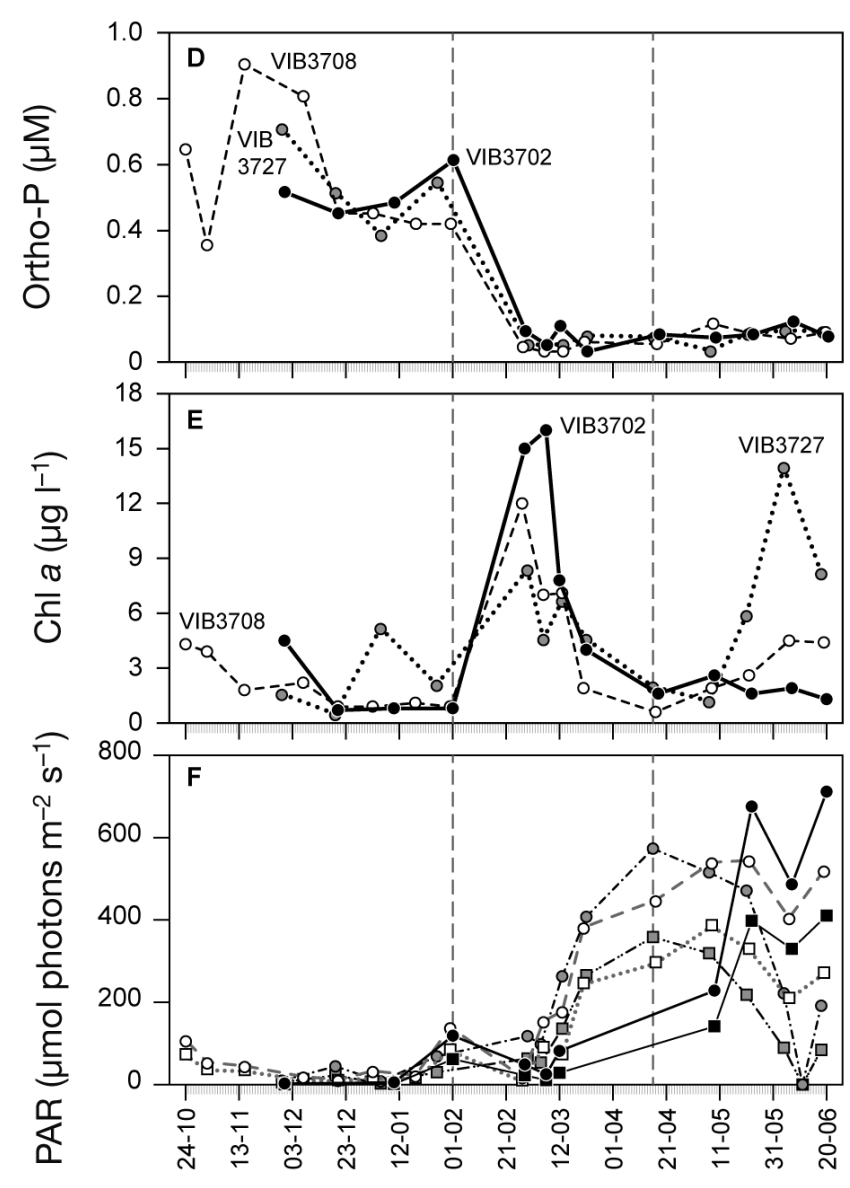

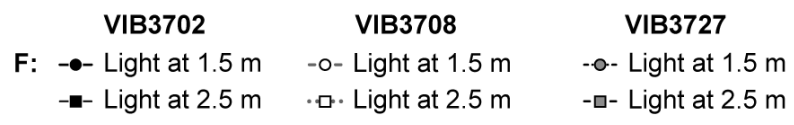

Fig. 2. Seasonal pattern of selected environmental parameters at the 3 pelagic stations (see Table 2) during the grow-out period of Saccharina latissima (October-December 2011 to June 2012): (A) salinity, (B) temperature, (C) dissolved inorganic nitrogen (DIN), (D) ortho-phosphate, (E) chlorophyll $a$ and (F) photosynthetically active radiation (PAR) estimated at the cultivation depths (1.5 and $2.5 \mathrm{~m}$ ). Data represent the actual measured values

spring, whereas the algae at $2.5 \mathrm{~m}$ only experienced up to $400 \mu \mathrm{mol}$ photons $\mathrm{m}^{-2} \mathrm{~s}^{-1}$ in the same period.

Overall, a high degree of inter-correlation between the key environmental parameters was observed (Table S1 in the Supplement). In early spring (February to April) the concentration of phytoplankton biomass (chl a) correlated strongly to the concentrations of dissolved inorganic nutrients. During early spring, the concentrations of pelagic chl a correlated positively to ortho-P, and negatively to DIN concentrations, whereas light availability correlated negatively to ortho-P concentrations. The DIN concentrations were negatively correlated to salinity. In late spring, the pelagic phytoplankton biomass was negatively correlated to salinity and positively to temperature.

\section{Saccharina latissima growth performance}

Biomass yield, frond length, SGR and biofouling

At all cultivation sites, the biomass yields and frond lengths were higher at $1.5 \mathrm{~m}$ than at $2.5 \mathrm{~m}$ depth (Fig. 3A,B, Table 3). The highest biomass yield in April (mean $\pm \mathrm{SE}: 510 \pm 66 \mathrm{~g} \mathrm{FW} \mathrm{m}^{-1}$ ) as well as the longest fronds in April and June (40.9 \pm $3.7 \mathrm{~cm}$ in April and $33.7 \pm 9.0 \mathrm{~cm}$ in June) were achieved at Færker Vig at $1.5 \mathrm{~m}$ (Fig. 3A,B, Table 4). In June, the biomass yield in Odby Bay and Færker Vig at $1.5 \mathrm{~m}$ was significantly higher than at the remaining 3 sites (Table 4 ). At $2.5 \mathrm{~m}$, the highest biomass yield in June was obtained in Odby 

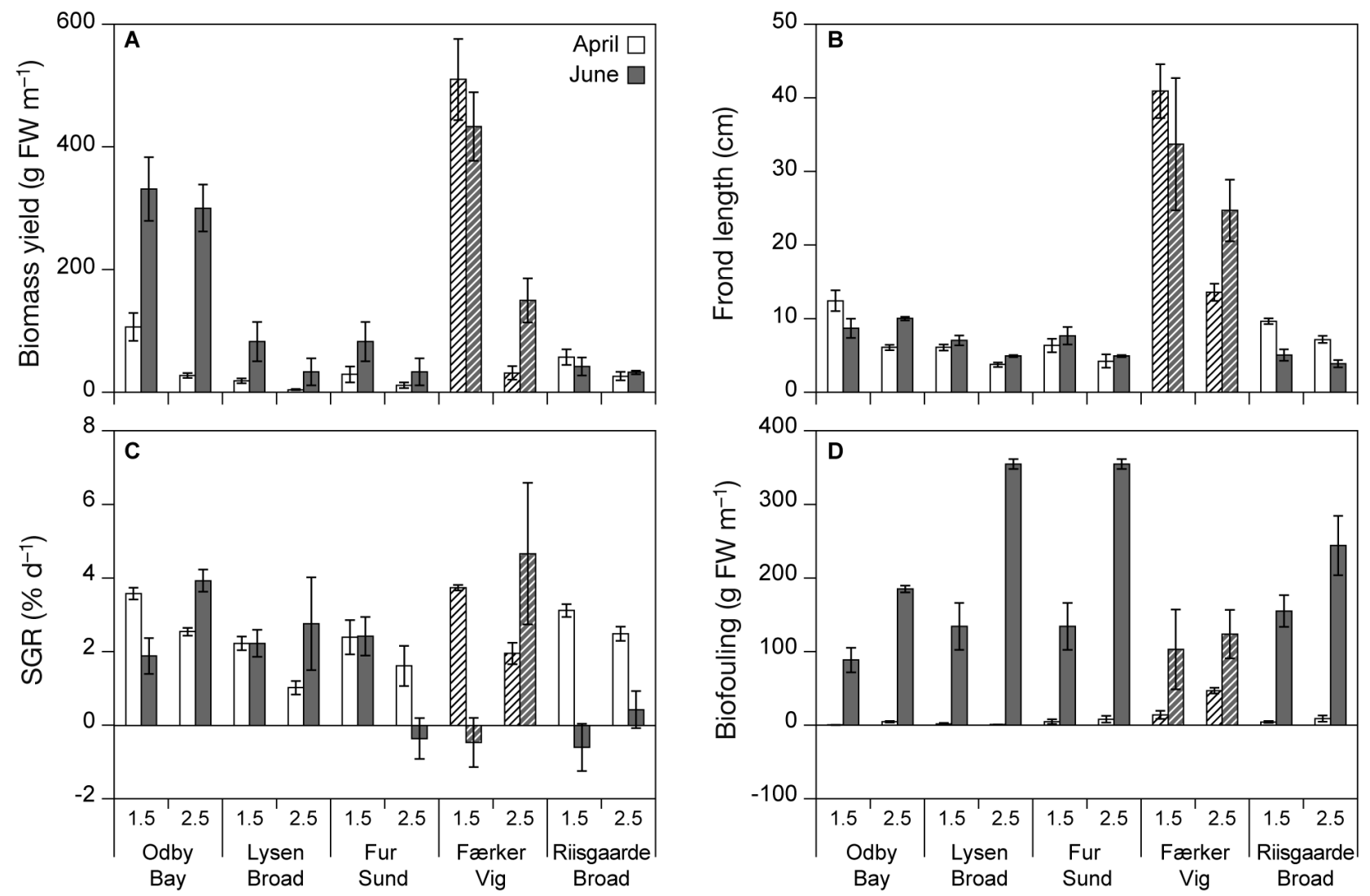

Cultivation site and depth $(\mathrm{m})$

Fig. 3. Growth performance and biofouling of Saccharina latissima at the 5 cultivation sites (see Fig. 1): (A) biomass yields, (B) average frond lengths $(\mathrm{n}=15),(\mathrm{C})$ specific growth rates (SGR), and (D) biofouling of $S$. latissima at 1.5 and $2.5 \mathrm{~m}$ depths at the 5 cultivation sites sampled in April (white bars) and June (grey bars), respectively. Solid bars represent batch 1 of seeded lines, and crossed bars represent batch 2 . Data represent means $\pm S E, n=3$

Bay, whereas the longest fronds were found in Færker Vig (Fig. 3A,B, Table 4).

The SGR (in the period from deployment to April) reflected the same pattern as the biomass yield at $1.5 \mathrm{~m}$ depth: Færker Vig $\left(3.8 \% \mathrm{~d}^{-1}\right)>$ Odby Bay $\left(3.7 \% \mathrm{~d}^{-1}\right)>$ Riisgaarde Broad $\left(3.1 \% \mathrm{~d}^{-1}\right)>$ Fur Sund $\left(2.4 \% \mathrm{~d}^{-1}\right)>$ Lysen Broad $\left(2.2 \% \mathrm{~d}^{-1}\right)$, and all with significantly higher SGRs at $1.5 \mathrm{~m}$ as compared to $2.5 \mathrm{~m}$ (Fig. 3C, Table 3). However, from April to June, the SGR decreased for the algae nearest to the surface $(1.5 \mathrm{~m})$ at Odby Bay, Færker Vig and Riisgaarde Broad and at the 2 latter sites to negative values. At Lysen Broad and Fur Sund, the SGR of the algae near the surface was constant throughout the full growout period. Regarding the algae growing at $2.5 \mathrm{~m}$ from April to June, diverging trends were observed: at 3 cultivation sites (Odby Bay, Lysen Broad and Færker Vig) the SGRs exceeded the SGRs at $1.5 \mathrm{~m}$ in the early growth period, whereas at the other 2 sites (Fur Sund and Riisgaarde Broad), the SGRs decreased to around or below zero.
The degree of biofouling increased dramatically at all sites from April to June, and was in June significantly higher at $2.5 \mathrm{~m}$ than at $1.5 \mathrm{~m}$ depth, with the one exception of Færker Vig (Fig. 3D). In June, the biomass yield of biofouling organisms (predominantly hydroids, juvenile $M$. edulis and ascidians) exceeded the biomass yields of $S$. latissima at 3 sites (Lysen Broad, Fur Sund and Riisgaarde Broad) at both depths (Fig. 3A,D).

In early spring, the growth performance (biomass increase [Fig. 4A], length growth and SGR) was positively correlated to the light availability, with also salinity and ortho-P availability being positively correlated to length growth and SGR (Fig. 4B, statistics are provided in Table S2 in the Supplement), respectively. The total biomass yield in June was negatively correlated to the degree of biofouling in late spring (linear regression, $\mathrm{p}=0.003, \mathrm{R}^{2}=0.28$ ). (Fig. $4 \mathrm{C}$ ). The biofouling in late spring was positively correlated to the sea temperature at the cultivation depth between April and June (Fig. 4D, Table S2). 


\section{Saccharina latissima biomass quality}

DM, tissue $\mathrm{N}$ and $\mathrm{P}$

The DM content of the algae varied between 6.3 and $16.8 \%$ of fresh weight (Fig. 5A). The C content generally ranged between 26.8 and $33.4 \%$ of DM, except at Fur Sund, where the C content was significantly lower (15.3-20.5\% of DM). At Odby Bay and Fur Sund, the tissue $C$ concentrations were significantly higher in the biomass closest to the surface. This was not the case at the other sites (Fig. 5B, Table 3).

The tissue $\mathrm{N}$ concentration in April was significantly higher in biomass from Odby Bay $(4.5 \%$ of DM) than from any of the other cultivation sites (3.5-4.0\% of DM) (Fig. 5C, Table 4). Only at Riisgaarde Broad was there a significantly higher $\mathrm{N}$ concentration in the algae cultivated at $2.5 \mathrm{~m}$ than at $1.5 \mathrm{~m}$ depth. The tissue $\mathrm{P}$ content was significantly higher in the algae cultivated at $2.5 \mathrm{~m}$ than at $1.5 \mathrm{~m}$ in Odby Bay and Riisgaarde Broad, where the P content in the algae from $2.5 \mathrm{~m}$ was up to $0.28 \%$ of DM compared to $0.11 \%$ of DM at $1.5 \mathrm{~m}$ (Fig. 5D).

The bio-mitigation capacity of $\mathrm{N}$ and $\mathrm{P}$ varied between sites and depths from (mean $\pm \mathrm{SE}$ ) $0.02 \pm 0.01$ to $1.84 \pm 0.24 \mathrm{~g} \mathrm{~N} \mathrm{~m}^{-1}$ and $0.001 \pm 0.0004$ to $0.05 \pm$ $0.01 \mathrm{~g} \mathrm{P} \mathrm{m}^{-1}$, respectively (Fig. 5E,F), reflecting predominantly the large fluctuations in biomass yields (Fig. 3A).

The environmental concentration of ortho-P was positively related to the tissue $\mathrm{DM}$ and $\mathrm{N}$ contents (Fig. 4B), while not related to the tissue P content
Table 3. Dependency of Saccharina latissima growth performance and biomass quality on cultivation site and depth, as well as the interaction between the two. p-values from 2-way ANOVA, data were $\log$ transformed prior to analysis. Statistical significance ( $p>0.05)$ is indicated in bold. A: April, J: June. (-) designates a negative correlation, otherwise the correlation is positive

\begin{tabular}{|c|c|c|c|}
\hline Parameter & $\begin{array}{l}\text { Cultivation } \\
\text { site } \times \text { Depth }\end{array}$ & $\begin{array}{l}\text { Cultivation } \\
\text { site }\end{array}$ & Depth \\
\hline \multicolumn{4}{|l|}{ Growth performance } \\
\hline Yield $\left(\mathrm{g} \mathrm{m}^{-1}\right)(\mathrm{A})$ & 0.064 & $<0.001$ & $<0.001(-)$ \\
\hline Yield $\left(\mathrm{g} \mathrm{m}^{-1}\right)(\mathrm{J})$ & 0.336 & $<0.001$ & $0.004(-)$ \\
\hline Length (cm) (A) & 0.014 & $<0.001$ & $<0.001(-)$ \\
\hline Length $(\mathrm{cm})(\mathrm{J})$ & 0.398 & $<0.001$ & $0.036(-)$ \\
\hline $\operatorname{SGR}\left(\% d^{-1}\right)(A)$ & 0.535 & 0.003 & $<0.001$ \\
\hline $\operatorname{SGR}\left(\% \mathrm{~d}^{-1}\right)(\mathrm{J})$ & 0.057 & 0.025 & 0.118 \\
\hline Biofouling $\left(\mathrm{g} \mathrm{m}^{-1}\right)(\mathrm{A})$ & 0.417 & $<0.001$ & 0.097 \\
\hline Biofouling $\left(\mathrm{g} \mathrm{m}^{-1}\right)(\mathrm{J})$ & 0.937 & 0.058 & 0.003 \\
\hline \multicolumn{4}{|l|}{ Biomass quality (A) } \\
\hline $\mathrm{DM}(\% \mathrm{FW})$ & 0.021 & $<0.001$ & 0.643 \\
\hline $\mathrm{C}(\% \mathrm{DM})$ & 0.030 & $<0.001$ & $<0.001(-)$ \\
\hline $\mathrm{N}(\% \mathrm{DM})$ & 0.001 & $<0.001$ & 0.959 \\
\hline $\mathrm{P}(\% \mathrm{DM})$ & 0.006 & 0.008 & $<0.001$ \\
\hline Chl a (mg g DM $\left.{ }^{-1}\right)$ & 0.029 & 0.005 & $<0.001$ \\
\hline Fucoxanthin (mg g DM-1) & 0.433 & 0.006 & $<0.001$ \\
\hline Violaxanthin (mg g DM ${ }^{-1}$ ) & 0.302 & 0.003 & 0.004 \\
\hline Beta-carotene $\left(\mathrm{mg} \mathrm{g} \mathrm{DM}^{-1}\right)$ & 0.316 & 0.026 & 0.005 \\
\hline As $\left(\mathrm{mg} \mathrm{kg} \mathrm{DM}^{-1}\right)$ & 0.249 & $<0.001$ & 0.003 \\
\hline $\mathrm{Hg}\left(\mathrm{mg} \mathrm{kg} \mathrm{DM}{ }^{-1}\right)$ & 0.057 & 0.050 & 0.761 \\
\hline $\mathrm{Pb}\left(\mathrm{mg} \mathrm{kg} \mathrm{DM}^{-1}\right)$ & 0.003 & $<0.001$ & $<0.001$ \\
\hline $\mathrm{Cd}\left(\mathrm{mg} \mathrm{kg} \mathrm{DM}{ }^{-1}\right)$ & 0.926 & $<0.001$ & 0.831 \\
\hline
\end{tabular}

(Table S2). Temperature was positively correlated to the tissue DM, N and P contents (Table S2). Light availability correlated positively to the tissue $\mathrm{C}$ content, but negatively to P content (Table S2).

Table 4. Tukey post-hoc pairwise comparisons of Saccharina latissima growth performance in April and June, and tissue biochemistry in April among cultivation sites at 1.5 and $2.5 \mathrm{~m}$ depth. Different letters are assigned to significantly different results. Fuco: fucoxanthin, Viola: violaxanthin, $\beta$-car: $\beta$-carotene

\begin{tabular}{|c|c|c|c|c|c|c|c|c|c|c|c|c|c|c|}
\hline Site & $\begin{array}{l}\text { Yield } \\
\text { (Apr) }\end{array}$ & $\begin{array}{l}\text { Yield } \\
\text { (Jun) }\end{array}$ & $\begin{array}{c}\text { Frond } \\
\text { length } \\
\text { (Apr) }\end{array}$ & $\begin{array}{c}\text { Frond } \\
\text { length } \\
\text { (Jun) }\end{array}$ & $\begin{array}{c}\text { Biofou- } \\
\text { ling } \\
\text { (Apr) }\end{array}$ & $\begin{array}{l}\text { Biofou- } \\
\text { ling } \\
\text { (Jun) }\end{array}$ & $\mathrm{DM}$ & $\mathrm{N}$ & $\mathrm{P}$ & $\mathrm{C}$ & Chl a & Fuco & Viola & $\beta$-car \\
\hline \multicolumn{15}{|l|}{$1.5 \mathrm{~m}$ depth } \\
\hline FærkerVig & A & $\mathrm{A}$ & $\mathrm{A}$ & A & $\mathrm{A}$ & $\mathrm{A}$ & B & B & A & B & $\mathrm{AB}$ & B & $\mathrm{AB}$ & A \\
\hline Odby Bay & $\mathrm{B}$ & $\mathrm{A}$ & $\mathrm{B}$ & $\mathrm{B}$ & $\mathrm{B}$ & $\mathrm{A}$ & $\mathrm{AB}$ & $\mathrm{A}$ & $\mathrm{A}$ & $\mathrm{A}$ & A & $\mathrm{A}$ & $\mathrm{A}$ & $\mathrm{A}$ \\
\hline Riisgaarde Broad & B & $\mathrm{B}$ & B & $\mathrm{B}$ & $\mathrm{AB}$ & $\mathrm{A}$ & $\mathrm{A}$ & $\mathrm{B}$ & $\mathrm{A}$ & $\mathrm{A}$ & $\mathrm{A}$ & B & $\mathrm{B}$ & $\mathrm{A}$ \\
\hline Fur Sund & B & B & B & B & $\mathrm{AB}$ & $\mathrm{A}$ & $\mathrm{C}$ & B & A & $\mathrm{C}$ & $\mathrm{B}$ & B & - & $\mathrm{A}$ \\
\hline Lysen Broad & B & B & B & B & $\mathrm{AB}$ & $\mathrm{A}$ & $\mathrm{A}$ & B & $\mathrm{A}$ & $\mathrm{A}$ & $\mathrm{A}$ & $\mathrm{AB}$ & $\mathrm{AB}$ & $\mathrm{A}$ \\
\hline \multicolumn{15}{|l|}{$2.5 \mathrm{~m}$ depth } \\
\hline Færker Vig & $\mathrm{A}$ & B & $\mathrm{A}$ & $\mathrm{A}$ & A & $\mathrm{C}$ & B & B & B & B & $\mathrm{BC}$ & $\mathrm{ABC}$ & $\mathrm{AB}$ & A \\
\hline Odby Bay & $\mathrm{A}$ & $\mathrm{A}$ & $\mathrm{BC}$ & B & $\mathrm{B}$ & $\mathrm{BC}$ & $\mathrm{A}$ & $\mathrm{A}$ & A & $\mathrm{AB}$ & $\mathrm{A}$ & A & A & $\mathrm{A}$ \\
\hline Riisgaarde Broad & $\mathrm{A}$ & B & $\mathrm{B}$ & B & B & B & $\mathrm{A}$ & $\mathrm{A}$ & $\mathrm{AB}$ & A & $\mathrm{AB}$ & $\mathrm{AB}$ & $\mathrm{AB}$ & $\mathrm{A}$ \\
\hline Fur Sund & $\mathrm{A}$ & $\mathrm{B}$ & $\mathrm{BC}$ & B & $\mathrm{B}$ & $\mathrm{A}$ & B & $\mathrm{C}$ & B & $\mathrm{C}$ & $\mathrm{C}$ & $\mathrm{C}$ & & $\mathrm{A}$ \\
\hline Lysen Broad & $\mathrm{A}$ & $\mathrm{B}$ & $\mathrm{C}$ & B & $\mathrm{B}$ & $\mathrm{A}$ & - & - & - & - & $\mathrm{BC}$ & $\mathrm{BC}$ & B & $\mathrm{A}$ \\
\hline
\end{tabular}



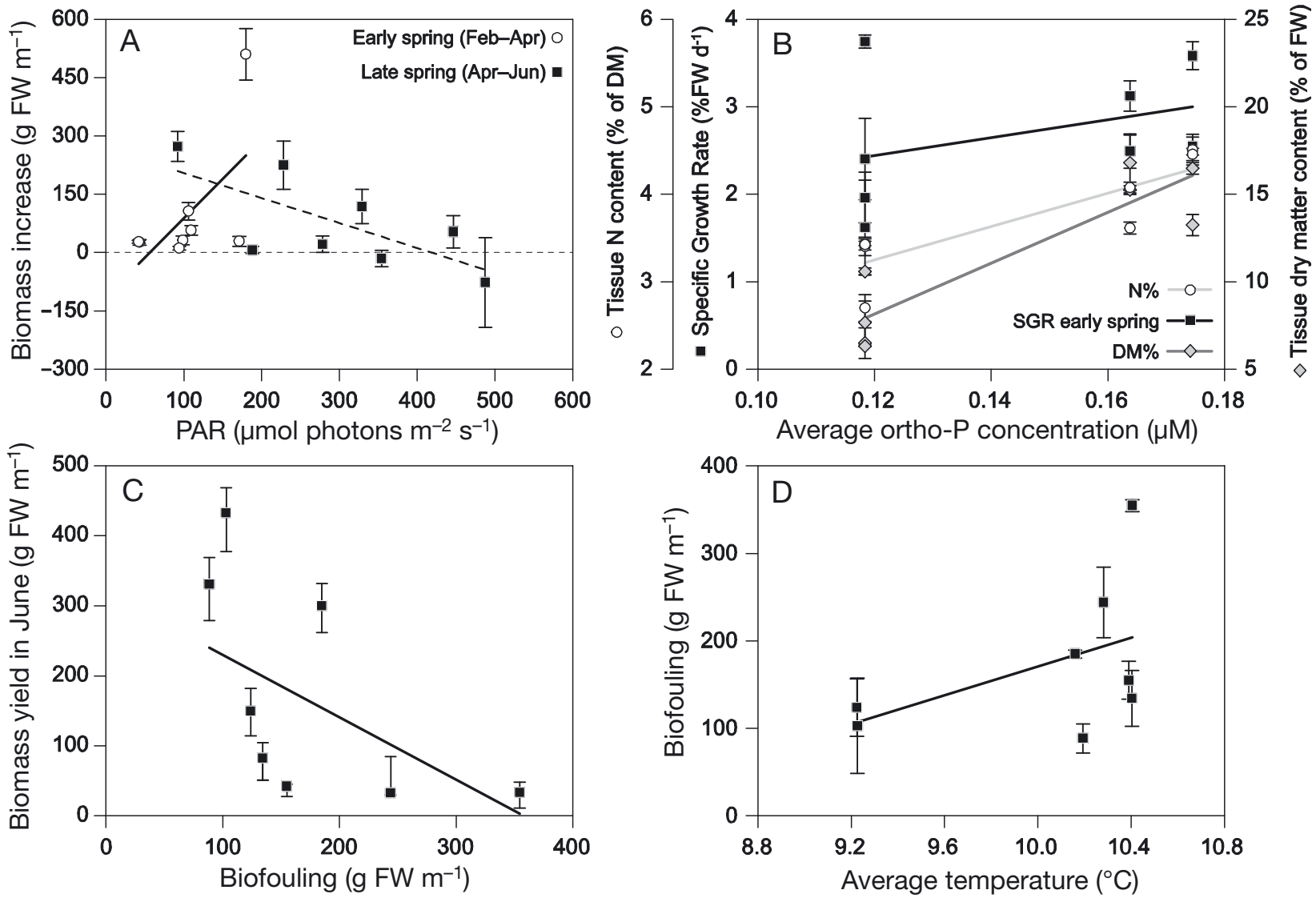

Fig. 4. Correlations between environmental parameters and Saccharina latissima biomass yields and quality. (A) Biomass increase or decrease in each of the 2 periods (early and late spring) as a function of light availability; (B) specific growth rate, tissue $\mathrm{N}$ and dry matter (DM) as a function of P availability in early spring; (C) biomass yield in June as a function of the biofouling in June (linear regression, $p=0.003, R^{2}=0.28$ ); (D) biofouling in June as a function of average water temperature. Data represent means $\pm \mathrm{SE}, \mathrm{n}=3$. Datapoints represent values for 4 stations ( 2 depths each). Significant correlations are indicated by solid lines, non-significant relations by dotted lines. Statistics for correlations in $(A, B, D)$ are given in Table S2 in the

Supplement at www.int-res.com/articles/suppl/q008p619_supp.pdf

The average molar tissue ratios of $\mathrm{C}: \mathrm{N}$ and $\mathrm{N}: \mathrm{P}$ were $($ mean $\pm \mathrm{SE}) 9.0 \pm 0.3$ and $69.7 \pm 4.8$, respectively, indicating strong P-limitation already in early spring (data not shown).

\section{Protein and AAs}

The content of crude protein in the $S$. latissima biomass from Færker Vig was $17.0 \pm 0.2 \%$ and $16.0 \pm$ $0.1 \%$ of DM in the biomass at $1.5 \mathrm{~m}$ and $2.5 \mathrm{~m}$, respectively. The essential AAs (EAAs) constituted $23.8 \pm 0.2$ and $27 \pm 1.9 \%$ of the total AAs (TAAs), at $1.5 \mathrm{~m}$ and $2.5 \mathrm{~m}$ depth, respectively. The specific EAA, methionine, constituted $1.25 \pm 0.04 \%(1.5 \mathrm{~m})$ and $1.37 \pm 0.10 \%(2.5 \mathrm{~m})$ of the TAAs, whereas another EAA, lysine, constituted $3.25 \pm 0.07 \%(1.5 \mathrm{~m})$ and $4.06 \pm 0.51 \%$ of TAAs $(2.5 \mathrm{~m})$.

\section{Pigments}

The tissue pigment contents ranged from 1.19$2.49 \mathrm{mg} \mathrm{chl}$ a $\mathrm{g} \mathrm{DM}^{-1}, 0.62-1.09 \mathrm{mg}$ fucoxanthin $\mathrm{g}$ $\mathrm{DM}^{-1}, 0.01-0.04 \mathrm{mg}$ violaxanthin $\mathrm{g} \mathrm{DM}^{-1}$ and 0.01-0.03 mg $\beta$-carotene g $\mathrm{DM}^{-1}$ (Fig. 6). Higher contents of fucoxanthin, violaxanthin and $\beta$ carotene were found in algae cultivated at $2.5 \mathrm{~m}$ depth, than at $1.5 \mathrm{~m}$. Also, there was a significant difference in the content of the 3 pigments among sites (Table 3), with algae cultivated at Odby Bay yielding the highest concentrations. Regarding chl $a$, there was a significant interaction effect between site and depth, with higher concentrations of chl $a$ at $2.5 \mathrm{~m}$ depth as compared to $1.5 \mathrm{~m}$ (Table 3), except at Lysen Broad, where no significant difference in the chl a content between cultivation depths was observed (Fig. 6A, Table 3). The 

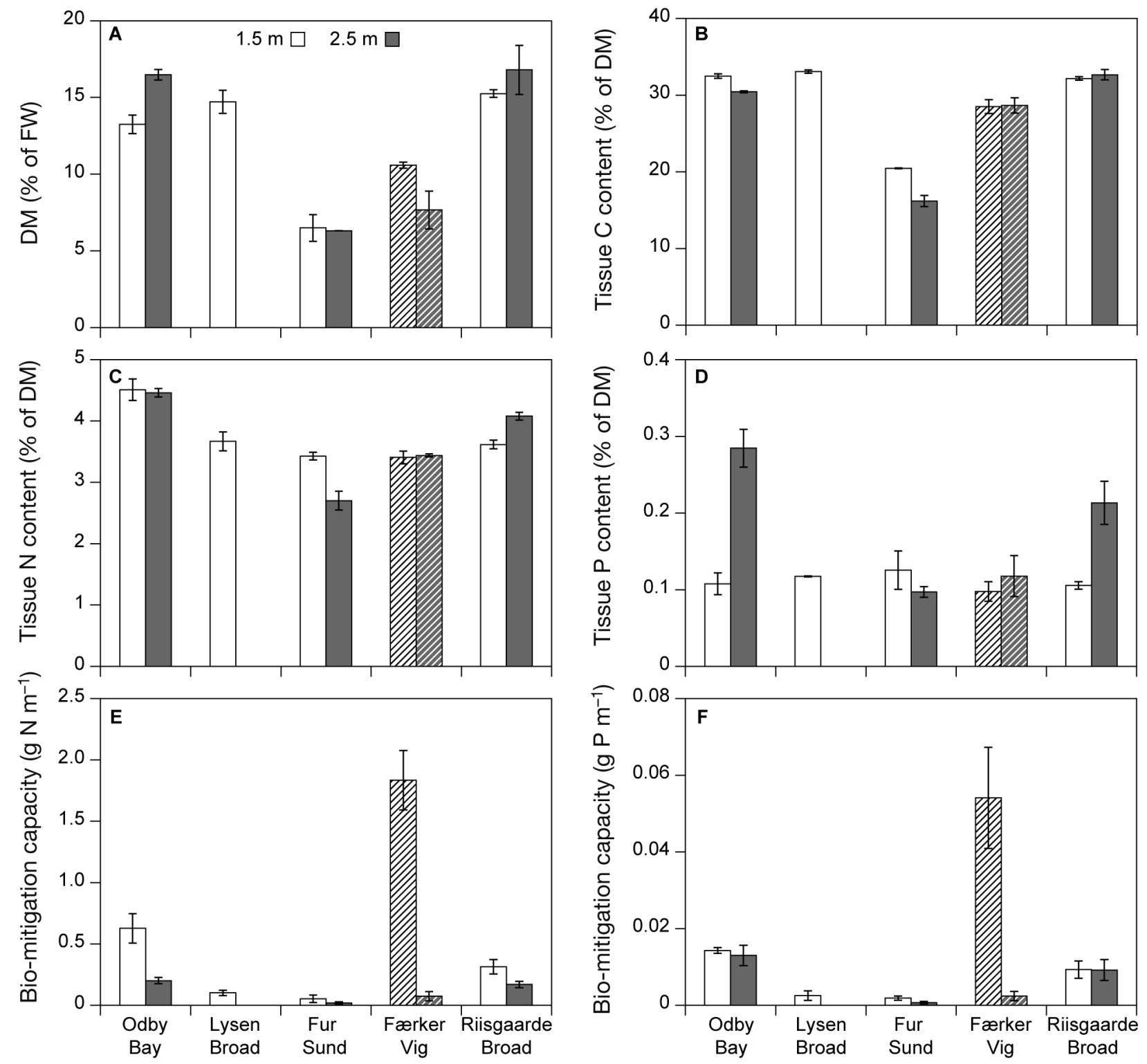

\section{Cultivation site}

Fig. 5. Tissue concentrations of (A) dry matter (DM; \% of fresh weight), (B) carbon (C), (C) nitrogen (N), (D) phosphorus (P), as well as bio-mitigation capacity of (E) N and (F) P of cultivation of Saccharina latissima harvested in April at the 5 cultivation sites at 1.5 (white bars) and $2.5 \mathrm{~m}$ depth (grey bars). Solid bars represent batch 1 of seeded lines, and crossed bars represent batch 2. Data represent means $\pm \mathrm{SE}, \mathrm{n}=3$

tissue concentrations of all pigments were negatively related to light availability (Table S2).

\section{Harmful metals}

The tissue concentrations of the harmful metals As $\mathrm{Pb}$ and $\mathrm{Cd}$ showed significant differences between sites and/or cultivation depths (Tables 3 \& 5), with higher concentration of $\mathrm{Pb}$ and lower concentrations of As at Fur Sund as compared to the other sites. No significant differences were observed in tissue $\mathrm{Hg}$ concentrations between sites and cultivation depths (Tables 3 \& 5).

Metal concentrations ranged between (mean \pm SE) $9.90 \pm 0.93$ and $31.67 \pm 1.07 \mathrm{mg} \mathrm{As} \mathrm{kg} \mathrm{DM}{ }^{-1}, 0.91 \pm$ 0.13 and $1.72 \pm 0.08 \mathrm{mg} \mathrm{Cd} \mathrm{kg} \mathrm{DM}^{-1}, 1.11 \pm 0.20$ and $17.60 \pm 3.33 \mathrm{mg} \mathrm{Pb} \mathrm{kg} \mathrm{DM}^{-1}$, and between $0.18 \pm 0.01$ and $1.03 \pm 0.40 \mathrm{mg} \mathrm{Hg} \mathrm{kg} \mathrm{DM}^{-1}$ (Table 5). The tissue concentrations of As were positively correlated to SGR (linear regression, $\mathrm{p}=0.004, \mathrm{R}^{2}=0.285, F=$ 10.556, $\mathrm{df}=23$, slope $=6.207$ ), whereas the tissue $\mathrm{Cd}$ 

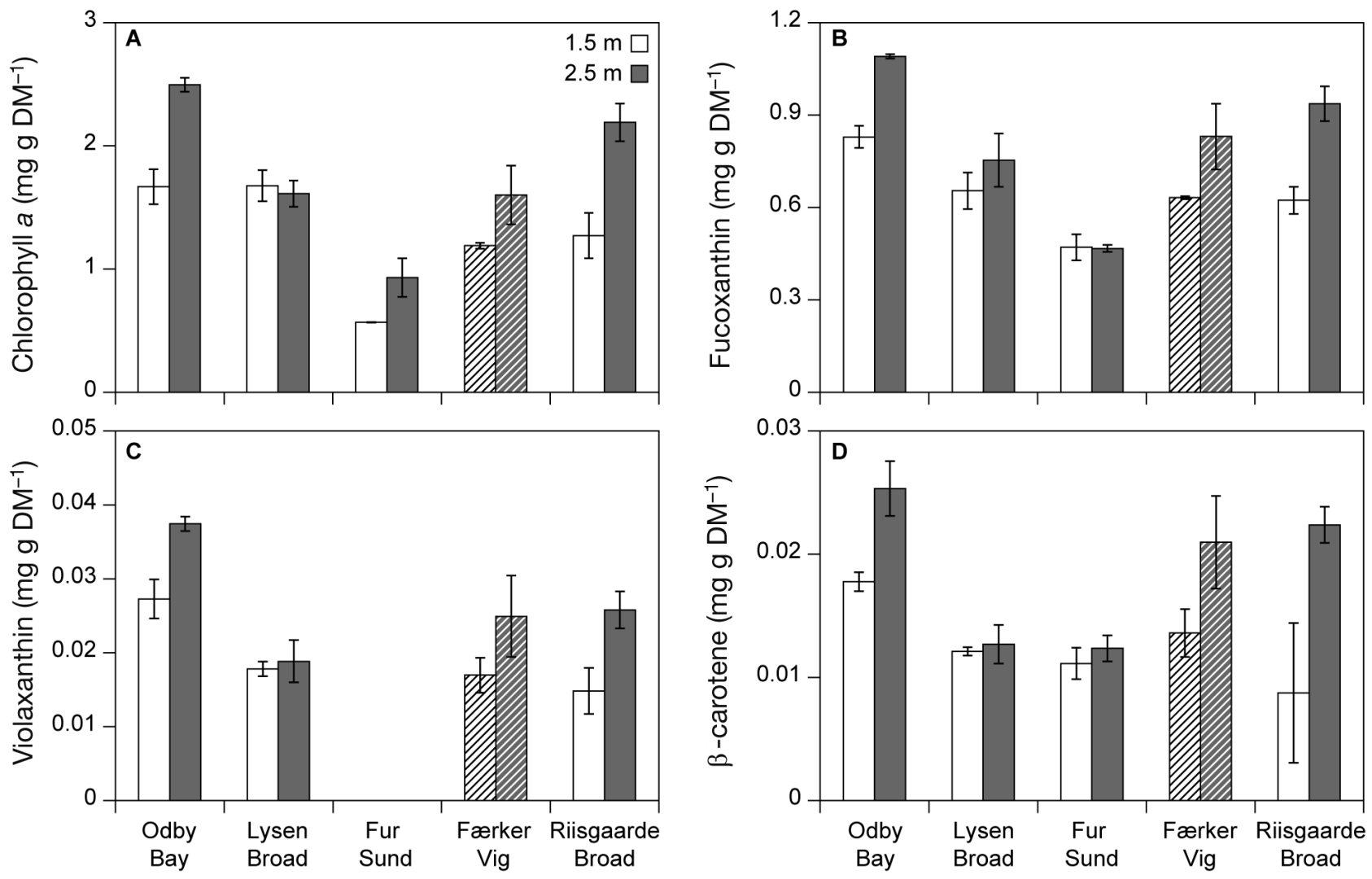

Cultivation site

Fig. 6. Tissue concentrations of the pigments (A) chlorophyll $a_{1}$ (B) fucoxanthin, (C) violaxanthin and (D) $\beta$-carotene in Saccharina latissima harvested in April, at 1.5 (white bars) and $2.5 \mathrm{~m}$ depths (grey bars). Solid bars represent batch 1 of seeded lines, and crossed bars represent batch 2. Data represent means $\pm \mathrm{SE}, \mathrm{n}=3$

concentrations were positively correlated to sediment concentrations of Cd (linear regression, $\mathrm{p}<$ $0.0001, \mathrm{R}^{2}=0.679, F=51.878, \mathrm{df}=23$, slope $=2.327$.

\section{DISCUSSION}

\section{Pelagic environment}

The lack of correlation between the availability of DIN and ortho-P indicated different origin of the 2 nutrients. The availability of DIN was negatively correlated to salinity, indicating input with freshwater run-off from the surrounding agricultural areas. The effect of freshwater run-off was also observed in Løgstør Broad and Skive Fjord as a decrease in salinity over the cultivation period.

The positive correlation between ortho-P and chl a indicated that the availability of $\mathrm{P}$ was controlling the primary production in Limfjorden in early spring, with DIN concentrations being too high to be limiting. P-limitation has previously been observed in eutrophic coastal regions, including parts of Limfjorden (Lyngby 1990, Holmboe et al. 1999, Lyngby et al. 1999, Pedersen et al. 2010), as a consequence of a more efficient sewage treatment reducing the emissions of $\mathrm{P}$ as compared to $\mathrm{N}$ to the marine environment (Conley et al. 2000, Kronvang et al. 2005). In late spring the lack of correlation between nutrients and pelagic phytoplankton biomass indicated that other factors came into play controlling phytoplankton biomass, potentially grazing (Maar et al. 2010), as also indicated by the increasing density of biofouling organisms (filter-feeders).

The general inverse reflection of the pelagic phytoplankton biomass ( $\mathrm{chl}$ a) by the photon flux density at cultivation depth indicated a close coupling between pelagic phytoplankton density and turbidity, as is common for Limfjorden (Krause-Jensen et al. 2012). However, impaired light conditions were also observed in winter in particular in Nissum Broad and Skive Fjord, most likely as a consequence of high wind speeds causing resuspension (Nissum) and/or soft sediment that is easily resuspended (Skive). 
Table 5. Tissue metal concentrations of the biomass harvested in April, expressed as ppm of fresh biomass (fresh weight) ( $\mathrm{mg} \mathrm{kg} \mathrm{FW}^{-1}$ ) and as ppm of dry matter (mg $\mathrm{kg} \mathrm{DM}^{-1}$ ). The concentrations are compared to the limit values of fresh biomass for food and food supplement according to the EU food legislation (EU 2008b), to the limit values of dry biomass for use in feed according to the EU feed legislation (EU 2013), as well as to the limit values according to the Danish regulations on sludge used as fertilizer (Danish Ministry of Environment 2006). Data are mean $\pm \mathrm{SE}, \mathrm{n}=$ 3. nd: no data. Underscored numbers indicate tissue concentrations exceeding limit values for food supplement. Numbers in bold indicate tissue concentrations exceeding limit values for feed, and numbers in italics indicate tissue concentrations exceeding limit values for use as fertilizer

\begin{tabular}{|c|c|c|c|c|c|}
\hline Cultivation site & $\begin{array}{c}\text { Depth } \\
\text { (m) }\end{array}$ & As & $\mathrm{Cd}$ & $\mathrm{Pb}$ & $\mathrm{Hg}$ \\
\hline \multicolumn{6}{|c|}{ Concentration in fresh biomass (mg kg FW ${ }^{-1}$ ) } \\
\hline \multirow[t]{2}{*}{ Odby Bay } & 1.5 & $4.02 \pm 0.18$ & $0.16 \pm 0.02$ & $0.15 \pm 0.03$ & $0.02 \pm 0.00$ \\
\hline & 2.5 & $3.31 \pm 0.21$ & $0.19 \pm 0.00$ & $1.09 \pm 0.03$ & $0.08 \pm 0.01$ \\
\hline \multirow[t]{2}{*}{ Lysen Broad } & 1.5 & $2.34 \pm 1.17$ & $0.16 \pm 0.08$ & $0.31 \pm 0.18$ & $0.04 \pm 0.02$ \\
\hline & 2.5 & nd & nd & nd & nd \\
\hline \multirow[t]{2}{*}{ Fur Sund } & 1.5 & $0.67 \pm 0.02$ & $0.06 \pm 0.00$ & $1.11 \pm 0.15$ & nd \\
\hline & 2.5 & $0.42 \pm 0.21$ & $0.04 \pm 0.02$ & $0.68 \pm 0.34$ & nd \\
\hline \multirow[t]{2}{*}{ Færker Vig } & 1.5 & $3.35 \pm 0.07$ & $0.11 \pm 0.01$ & $0.27 \pm 0.08$ & $0.04 \pm 0.01$ \\
\hline & 2.5 & $2.08 \pm 0.60$ & $0.08 \pm 0.02$ & $0.26 \pm 0.04$ & $0.02 \pm 0.01$ \\
\hline \multirow[t]{2}{*}{ Riisgaarde Broad } & 1.5 & $3.38 \pm 0.18$ & $0.26 \pm 0.01$ & $0.20 \pm 0.02$ & $\underline{0.16 \pm 0.06}$ \\
\hline & 2.5 & $3.18 \pm 0.51$ & $0.27 \pm 0.03$ & $0.43 \pm 0.02$ & $0.08 \pm 0.01$ \\
\hline \multicolumn{6}{|c|}{ Limit values, fresh biomass } \\
\hline \multicolumn{3}{|c|}{ Mussels } & 1 & 1.5 & 0.5 \\
\hline \multicolumn{2}{|l|}{ Fish meat } & - & $0.05-0.3$ & 0.3 & $0.05-1$ \\
\hline \multicolumn{2}{|l|}{ Food supplement } & - & $1-3^{\mathrm{a}}$ & 3 & 0.1 \\
\hline \multicolumn{6}{|c|}{ Concentration in dry biomass (mg kg $\mathrm{DM}^{-1}$ ) } \\
\hline \multirow[t]{2}{*}{ Odby Bay } & 1.5 & $30.37 \pm 0.38$ & $1.19 \pm 0.06$ & $1.11 \pm 0.20$ & $0.18 \pm 0.01$ \\
\hline & 2.5 & $20.06 \pm 0.87$ & $1.18 \pm 0.02$ & $6.65 \pm 0.28$ & $0.51 \pm 0.06$ \\
\hline \multirow[t]{2}{*}{ Lysen Broad } & 1.5 & $24.65 \pm 1.09$ & $1.42 \pm 0.06$ & $3.60 \pm 0.70$ & $0.32 \pm 0.08$ \\
\hline & 2.5 & nd & nd & nd & nd \\
\hline \multirow[t]{2}{*}{ Fur Sund } & 1.5 & $10.61 \pm 1.38$ & $0.91 \pm 0.13$ & $17.60 \pm 3.33$ & nd \\
\hline & 2.5 & $9.90 \pm 0.93$ & $0.94 \pm 0.01$ & $16.20 \pm 0.16$ & nd \\
\hline \multirow[t]{2}{*}{ Færker Vig } & 1.5 & $31.67 \pm 1.07$ & $1.08 \pm 0.11$ & $2.55 \pm 0.83$ & $0.39 \pm 0.10$ \\
\hline & 2.5 & $26.11 \pm 3.40$ & $1.04 \pm 0.12$ & $3.66 \pm 0.91$ & $0.35 \pm 0.15$ \\
\hline \multirow[t]{2}{*}{ Riisgaarde Broad } & 1.5 & $22.15 \pm 0.83$ & $1.72 \pm 0.08$ & $1.34 \pm 0.10$ & $1.03 \pm 0.40$ \\
\hline & 2.5 & $18.65 \pm 1.42$ & $1.63 \pm 0.03$ & $2.63 \pm 0.31$ & $0.51 \pm 0.07$ \\
\hline \multicolumn{6}{|c|}{ Limit values, dry biomass } \\
\hline \multicolumn{3}{|c|}{ Feed $\quad 40\left(10^{\mathrm{b}}\right)$} & $1-2^{\mathrm{b}}$ & $5^{\mathrm{b}}-10$ & \\
\hline \multicolumn{2}{|l|}{ Sludge } & $25^{\mathrm{c}}$ & 0.8 & 120 & 0.8 \\
\hline
\end{tabular}

with a shorter grow-out period (84 vs. $166 \mathrm{~d}$ at Færker Vig) (Forbord et al. 2012), and the sporophyte lengths obtained at Lysen Broad were fully comparable to earlier trials at the same site (Wegeberg 2010). Only sporophytes obtained in the German Baltic Sea were smaller, with maximum lengths of $20 \mathrm{~cm}$ obtained in a $1 \mathrm{yr}$ grow-out period (Rössner \& Krost 2012). The low biomass yields were explained by several factors: (1) light limitation; (2) P-limitation reducing the SGR, and contents of DM and $\mathrm{N}$ in the biomass, and (3) the high degree of biofouling forcing an early harvest.

The higher yield observed at Færker Vig was most likely a consequence of the combination of less turbid waters at this site during winter and early spring as well as the earlier deployment (October instead of December), which may have given the juvenile sporophytes there a head start in growth, as has been documented from trials in Spain and Ireland (Peteiro \& Freire 2009, Edwards \& Watson 2011). The fact that the sporophytes were derived from a different batch of seeded lines and potentially could have been of superior quality was not supported by visual inspection at deployment. Comparing only sporophytes from Batch 1, the growth performance was best at Odby Bay, where light conditions improved markedly from April to June.

The results in general support light as a main controlling factor for growth of cultivated $S$. latissima in Limfjorden in spring. In early spring, light was positively correlated to growth and the average PAR (100-400 $\mu \mathrm{mol}$ pho-

\section{Biomass yield and growth performance}

The Saccharina latissima biomass yields and sporophyte lengths obtained at the 5 sites in Limfjorden were generally low compared to values reported from other cultivation trials in Europe (Peteiro \& Freire 2009, 2013b, Edwards \& Watson 2011, Forbord et al. 2012, Handå et al. 2013), and in particular in Denmark (Marinho et al. 2015a, Nielsen 2015). The frond lengths were comparable to trials from Norway tons $\mathrm{m}^{-2} \mathrm{~s}^{-1}$ ) reflected a photon flux density within the range reported to saturate photosynthesis of $S$. latissima $\left(\mathrm{E}_{\mathrm{sat}} 20-500 \mu \mathrm{mol}\right.$ photons $\mathrm{m}^{-2} \mathrm{~s}^{-1}$; Bartsch et al. 2008). In contrast, in late spring, the available PAR exceeded $E_{\text {sat, }}$ and in this period the higher average PAR appeared to have a negative effect on growth since mainly the sporophytes from the deepest cultivation depth showed increased growth rates between April and June. A positive correlation between frond length and salinity has previously 
been suggested (Nielsen et al. 2014), and reduced frond length at lower salinities may be a consequence of increased allocation of energy to osmoregulation at the expense of growth.

The high turbidity of the waters in Limfjorden generally limited the extent of the vertical production potential. The turbidity in Limfjorden is primarily a consequence of high nutrient loadings supporting a high pelagic primary production (Krause-Jensen et al. 2012). Historically, the primary production in marine waters is considered to be controlled by $\mathrm{N}$ availability (Howarth 1988). Limfjorden, however, is an estuary with strong influence of freshwater run-off from agricultural land, and in this study, DIN was available in the water column until late spring/early summer. The limiting nutrient appeared to be $\mathrm{P}$, since the bioavailable $\mathrm{P}$ disappeared with the onset of the phytoplankton spring bloom in early spring, and subsequently, $\mathrm{P}$ availability appeared to control the primary production. That $\mathrm{P}$ rather than $\mathrm{N}$ availability controlled the growth performance of $S$. latissima in this study was supported by several observations: tissue N:P ratios were, already in early spring, almost 3 times as high as other reports of kelp N:P ratios (9-25:1) (Atkinson \& Smith 1983); the tissue $P$ contents were generally below the $\mathrm{P}$ concentration defined as being critical for growth $(0.22 \%$ P of DM, $69.4 \mu \mathrm{mol} \mathrm{P} \mathrm{g}{ }^{-1} \mathrm{DM}$ ) as suggested by Pedersen et al. (2010), whereas the tissue $\mathrm{N}$ concentrations were not below the concentrations critical for growth $\left(\mathrm{N}_{\mathrm{C}}\right)$ of 1.71, as suggested for brown algae (Pedersen \& Borum 1997), and 1.88 specifically for S. latissima (Chapman et al. 1978), and finally, SGRs in early spring corresponded positively to the ortho-P concentrations. Phosphorus limitation of macroalgae growth has previously been observed (Pedersen et al. 2010).

Biofouling of the biomass precluded a late summer harvest of the sporophytes and thus, a biomass buildup over summer. Devastation of biomass by biofouling has been reported from cultivation trials in Norway (Handå et al. 2013), Spain (Peteiro \& Freire 2013a) as well as from other trials in Denmark (Wegeberg 2010, Marinho et al. 2015a, Nielsen 2015), and the phenomenon appears to be coupled to relatively sheltered locations with established natural or cultured populations of suspension-feeders. Temperature generally exerts positive control on the growth and development of juvenile filter-feeders (Widdows 1991, Nasrolahi et al. 2013), and in this study biofouling was positively correlated to temperature, even within a very narrow range of temperature differences. In the eutrophic environment in
Limfjorden, food (phytoplankton) is not a limiting factor for the juvenile filter-feeders, whereas suitable substrate for settling might be. Thus, any substrate introduced in the water column, including macroalgae sporophytes, has the risk of becoming fully overgrown. In this study, the degree of biofouling was most pronounced at the deeper cultivation depths, but did not correspond to the estimated degree of exposure at the individual cultivation sites. The negative correlation between biofouling and length growth may indicate that heavily bio-fouled fronds did not grow well, or that once the fronds were sufficiently long in early spring, they were able to avoid the biofouling, the latter partly being supported by recent findings showing that dense natural kelp canopies tend to be less prone to settling of epiphytic organisms (Bennett et al. 2015).

\section{Biomass quality}

If harvested before the onset of biofouling, S. latissima cultivated in Færker Vig, Limfjorden, provided a rich source of protein, essential AAs and pigments with bioactive properties suitable for food or feed purposes. Availability of ortho-P influenced the quality of the biomass, significantly increasing tissue DM and $\mathrm{N}$ content.

As for growth performance, the biochemical composition of S. latissima biomass showed large differences among cultivations sites. Tissue P concentrations were generally in the same range as reported from cultivation trials in Kattegat, Denmark (Marinho et al. 2015a). A doubling of tissue P concentrations in macroalgae cultivated at $2.5 \mathrm{~m}$ depth at 2 sites (Odby Bay and Riisgaarde Broad), where the seabed was characterized by soft mud, indicated local differences in resuspension events as also indicated by the poorer light conditions at these sites during winter and early spring. The N content of $3-4.5 \%$ of DM in April was high for this time of the year compared to natural populations and cultivated biomass from other locations in Denmark (Nielsen et al. 2014, 2016, Marinho et al. 2015a) and was more comparable to $\mathrm{N}$ contents obtained in close proximity to fish farms or in late autumn/winter months where environmental $\mathrm{N}$ concentrations are naturally higher (Gevaert et al. 2001, Handå et al. 2013).

The high tissue $\mathrm{N}$ concentrations were indicative of high tissue protein concentration in the range of 16.0-17.0\%. Compared to other cultivation trials in Denmark, this protein content was high for April (Marinho et al. 2015b), but comparable to what has 
been reported elsewhere (Black 1950). The ratio of EAAs, and the content of methionine and lysine in the biomass in Færker Vig were higher than described from $S$. latissima biomass cultivated in proximity to fish cages, and thus the S. latissima biomass from Limfjorden represented a biomass with an attractive profile for applications within food or feed (Marinho et al. 2015b).

Light availability influenced biomass quality, correlating positively to tissue $\mathrm{C}$ content, but negatively to the tissue concentrations of $\mathrm{P}$ and all pigments. The pigment contents in $S$. latissima from the 5 sites varied by a factor of $2-5$ and were generally high due to the turbid conditions, in particular in the deeper cultivated biomass. The tissue contents of chl $a$ and fucoxanthin in the biomass were up to 8 and 5 times higher, respectively, than the tissue contents in $S$. latissima fronds cultivated in autumn under low light conditions in tanks (Boderskov et al. 2016). The antioxidant and other bioactive properties of fucoxanthin have recently drawn attention as being active against obesity and diabetes (Miyashita et al. 2011, D'Orazio et al. 2012). Thus, high contents of this pigment in kelp biomass are attractive for applications in (functional) food and feed.

The positive effects of temperature on DM, N and P tissue contents may in part be explained by increased activity of enzymes involved in nutrient assimilation over the range of temperatures experienced during early spring (Davison \& Davison 1987).

Only extreme levels of pollution are considered to cause significant reduction in production of marine plants (Sharp et al. 1988); however, tissue concentrations of specific metals (i.e. As, $\mathrm{Cd}, \mathrm{Hg}$ and $\mathrm{Pb}$ ) may prevent the use of the produced biomass for food, food supplement, feed or fertilizer (Miljøstyrelsen 2006, EU 2008b, 2013). In this study, we only had access to sediment concentrations of selected metals from the national environmental monitoring program, as water concentrations are not monitored. For this reason, we had no basis for estimating the environmental metal concentrations experienced by the algae, and the potential direct consequential physiological impacts. However, through the sediment concentrations, we may get an indication of the local level of environmental pollution and an indication of whether this may be a predictive tool in future site selection. The tissue concentrations of $\mathrm{As}, \mathrm{Pb}$ and $\mathrm{Hg}$ fluctuated by a factor of 3-5 between the 5 cultivation sites, whereas the tissue concentrations of $\mathrm{Cd}$ were relatively constant. The tissue metal concentrations in this study did not exceed the limit values set for human consumption, and only at one site (Riis- gaarde Broad) would the tissue $\mathrm{Hg}$ concentrations prevent the use of the biomass for food supplements. For use in animal feed, the $\mathrm{Pb}$ concentrations in the biomass cultivated at Fur Sund and Odby Bay $(2.5 \mathrm{~m})$ exceeded limit values, whereas the Cd concentrations would prevent the use for fertilizer of the biomass cultivated at any of the sites (limit value = $0.8 \mathrm{mg} \mathrm{kg} \mathrm{DM}{ }^{-1}$, Danish Ministry of Environment 2006). The As concentrations found in this study did not exceed limit values for use in food or feed, and they were generally lower than what has been found in natural populations in more open Danish waters (Nielsen et al. 2016). Since tissue As concentrations were positively correlated to growth, bioaccumulation may explain the higher As concentrations found in older individuals in natural populations, as compared to the 1-yr-old cultivated individuals in this study. The linear correlation between tissue and sediment $\mathrm{Cd}$ concentrations indicated that elevated sediment concentrations of $\mathrm{Cd}$ may cause increased availability and hence uptake into the seaweed tissue. At the 2 stations with the highest sediment $\mathrm{Cd}$ concentrations (Riisgaarde: $0.44 \mathrm{ppm}$ and Lysen: $0.25 \mathrm{ppm}$ ), the seabed sediment and depth, as well as the degree of exposure, differed. At Riisgarde the sediment was soft and muddy, and a high degree of exposure increased the risk of resuspension of the sediment into the water column, potentially increasing the availability of $\mathrm{Cd}$ to the seaweed. Below the cultivation structures at the more sheltered and shallow site in Lysen Broad, the seabed consisted of fine sand and clay, and there the depth was lower. Thus, despite different conditions regarding sediment, depth and exposure, the sediment concentration of $\mathrm{Cd}$ demonstrated a potential value as an instrument in site selection.

\section{Bio-mitigation}

The bio-mitigation capacity of $S$. latissima in this study proved to be relatively poor in comparison with other studies of Laminariales in Denmark (Marinho et al. 2015a) and Scotland (Sanderson et al. 2012), where up to 4 and 1.4 times more $\mathrm{N}$ was removed per metre of seeded line, respectively. The low biomitigation capacity was primarily a consequence of the low biomass yields obtained due to turbid waters, P-limitation and biofouling. Thus, in highly eutrophic waters such as Limfjorden, the pelagic primary productivity limits the efficiency of kelp cultivation as a tool for bio-mitigation of $\mathrm{N}$. Consequently, care should be taken when extrapolating the bio-mitigation ca- 
pacities described in the literature to any cultivation site assuming high areal productivity (i.e. Holdt \& Edwards 2014). This study highlights the limitations and challenges of kelp production for bio-mitigation purposes in eutrophic waters, where bio-mitigation is needed the most.

\section{Site selection}

Even within the relatively homogenous eutrophic Limfjorden, production yields varied by a factor of 10 between different basins. Environmental monitoring data proved useful as predictive instruments for site selection. Regarding the pelagic parameters, generally, highly N-enriched sites with low light availability, high pelagic N:P ratios and high chl a concentrations should be avoided, as they supported a lower biomass production and, in conjunction with marginally higher temperatures during spring, also presented a higher risk of biofouling.

Regarding sediment characteristics, 2 recommendations for site selection are suggested: (1) kelp cultivation should be reconsidered in shallow areas dominated by soft muddy seabed, as resuspension events tend to increase turbidity; and (2) sediment Cd concentrations could be investigated as a part of site selection. High sediment Cd concentrations were reflected as high $\mathrm{Cd}$ concentrations in seaweed biomass, and depending on the post-harvest use of the biomass, high tissue $\mathrm{Cd}$ concentrations may have a strong negative impact on biomass value.

\section{CONCLUSIONS}

Basin-scale differences in light and nutrient availability, seabed properties and sediment metal concentrations cause pronounced local differences in the suitability of an area for cultivation of Saccharina latissima in terms of biomass yield and quality as well as bio-mitigation, and hence, impact the profitability of potential seaweed production. When selecting sites for cultivation of $S$. latissima, highly N-enriched sites with low light availability, high pelagic N:P ratios and chl a concentrations, and high sediment Cd concentration should be avoided. The highly Nenriched waters of Limfjorden appeared less suitable for efficient biomass production of S. latissima due to reduced light conditions and P-limitation in early spring, and a high risk of devastating biofouling impairing growth performance, bio-mitigation capacity as well as biomass quality. However, S. latissima bio- mass harvested in spring in Limfjorden had a high content of pigments and protein with a beneficial amino acid composition, and proved highly suitable for food or feed purposes.

Acknowledgements. The work behind this article was supported by 'De Lokale Dyder' (The Market Development Fund), the PEER project on improved resource flows between human and natural systems, the Macroalgae Biorefinery (MAB3) (Danish Council for Strategic Research) and finally a grant supplied by the National Centre for Environment and Energy (DCE). The authors thank Kristian Oddershede Nielsen, Helge Boesen, Finn Bak and Pascal Barreau for the field work, Tanja Quottrup Egholm, Kitte Linding Gerlich, Gitte Jacobsen, Anne Marie Plejdrup and Peter Kofoed for skillful lab work, Ole Manscher and David Rytter for extraction of data from ODAM, Tinna Christensen for graphical assistance and 3 anonymous reviewers for constructive comments improving the manuscript.

\section{LITERATURE CITED}

Angell A, Mata L, de Nys R, Paul N (2016) The protein content of seaweeds: a universal nitrogen-to-protein conversion factor of five. J Appl Phycol 28:511

Atkinson MJ, Smith SV (1983) C-N-P ratios of benthic marine plants. Limnol Oceanogr 28:568-574

Bartsch I, Wiencke C, Bischof $\mathrm{K}$, Buchholz CM and others (2008) The genus Laminaria sensu lato: recent insights and developments. Eur J Phycol 43:1-86

* Bennett S, Wernberg T, de Bettignies T, Kendrick GA and others (2015) Canopy interactions and physical stress gradients in subtidal communities. Ecol Lett 18:677-686

Black WAP (1950) The seasonal variation in weight and chemical composition of the common British Laminariaceae. J Mar Biol Assoc UK 29:45-72

Boderskov T, Schmedes PS, Bruhn A, Rasmussen MB, Nielsen MM, Pedersen MF (2016) The effect of light and nutrient availability on growth, nitrogen, and pigment contents of Saccharina latissima (Phaeophyceae) grown in outdoor tanks, under natural variation of sunlight and temperature, during autumn and early winter in Denmark. J Appl Phycol 28:1163-1165

Bruton T, Lyons H, Lerat Y, Stanley M, Rasmussen B (2009) A review of the potential of marine algae as a source of biofuel in Ireland. Sustainable Energy Authority of Ireland, Dublin

Buck BH, Buchholz CM (2004) The offshore-ring: a new system design for the open ocean aquaculture of macroalgae. J Appl Phycol 16:355-368

* Buck BH, Buchholz CM (2005) Response of offshore cultivated Laminaria saccharina to hydrodynamic forcing in the North Sea. Aquaculture 250:674-691

Buck BH, Krause G, Michler-Cieluch T, Brenner M and others (2008) Meeting the quest for spatial efficiency: progress and prospects of extensive aquaculture within offshore wind farms. Helgol Mar Res 62:269-281

Castine SA, McKinnon AD, Paul NA, Trott LA, De Nys R (2013) Wastewater treatment for land-based aquaculture: improvements and value-adding alternatives in model systems from Australia. Aquacult Environ Interact $4: 285-300$ 
Chapman ARO, Markham JW, Lüning K (1978) Effects of nitrate concentrations on the growth and physiology of Laminaria saccharina (Phaeophyta) in culture. J Phycol 14:195-198

Christiansen T, Christensen TJ, Markager S, Petersen JK, Mouritsen LT (2006) Limfjorden i 100 år. Klima, hydrografi, næringsstoftilførsel, bundfauna og fisk i Limfjorden fra 1897 til 2003. Report 578. National Environmental Research Institute, Roskilde

Conley DJ, Kaas H, Møhlenberg F, Rasmussen B, Windolf J (2000) Characteristics of Danish estuaries. Estuaries 23: 820-837

Coquery M, Carvalho FP, Azemard S, Bachelez M, Horvat M (2000) Certification of trace and major elements and methylmercury concentrations in a macroalgae (Fucus sp.) reference material, IAEA-140. Fresenius J Anal Chem 366:792-801

Culmo RF (2010) Methods of organic nitrogen analysis: Kjeldahl and the EA2410 N Analyzer (Dumas Method). PerkinElmer publication EAN-8

W'Orazio N, Gemello E, Gammone MA, de Girolamo M, Ficoneri C, Riccioni G (2012) Fucoxantin: a treasure from the sea. Mar Drugs 10:604-616

Daly HE (1998) The return of Lauderdale's paradox. Ecol Econ 25:21-23

Danish Ministry of Environment (2006) Anvendelse af affald til jordbrugsformål. BEK nr 1650 af 13/12/2006 (Slambekendtgørelsen). Danish Ministry of Environment, Copenhagen

Davison IR, Davison JO (1987) The effect of growth temperature on enzyme activities in the brown alga Laminaria saccharina. Br Phycol J 22:77-87

Edwards M, Watson L (2011) Cultivating Laminaria digitata. BIM Aquaculture Explained 26. Irish Sea Fisheries Board, Dublin

EU (2008a) Marine Strategy Framework Directive. 2008/56/ EC. Off J Eur Union L164:19-40

EU (2008b) Commission regulation (EC) No 629/2008 of 2 July 2008 amending Regulation (EC) No 1881/2006 setting maximum levels for certain contaminants in foodstuffs. Off J Eur Union L 173:6-9

EU (2013) Commission regulation (EU) No 1275/2013 of 6 December 2013 -amending Annex I to Directive 2002/ $32 / \mathrm{EC}$ of the European Parliament and of the Council as regards maximum levels for arsenic, cadmium, lead, nitrites, volatile mustard oil and harmful botanical impurities. Off J Eur Union L 328:86-92

EU (2014) Establishing a framework for maritime spatial planning 2014/89/EU. Off J Eur Union L 257:135-145

FAO (2016) The state of world fisheries and aquaculture 2016. Contributing to food security and nutrition for all. FAO, Rome. www.fao.org/3/a-i5555e

Forbord S, Skjermo J, Arff J, Handa A, Reitan KI, Bjerregaard R, Lüning K (2012) Development of Saccharina latissima (Phaeophyceae) kelp hatcheries with yearround production of zoospores and juvenile sporophytes on culture ropes for kelp aquaculture. J Appl Phycol 24: 393-399

Gevaert F, Davoult D, Creach A, Kling R, Janquin MA, Seuront L, Lemoine Y (2001) Carbon and nitrogen content of Laminaria saccharina in the eastern English Channel: biometrics and seasonal variations. J Mar Biol Assoc UK 81:727-734

Grasshoff K, Ehrhardt M, Kremling K (1983) Methods of seawater analysis. Verlag Chemie, Weinheim
Handå A, Forbord S, Wang XX, Broch OJ and others (2013) Seasonal- and depth-dependent growth of cultivated kelp (Saccharina latissima) in close proximity to salmon (Salmo salar) aquaculture in Norway. Aquaculture 414-415:191-201

Holdt SL, Edwards MD (2014) Cost-effective IMTA: a comparison of the production efficiencies of mussels and seaweed. J Appl Phycol 26:933-945

*Holmboe N, Jensen HS, Andersen FØ (1999) Nutrient addition bioassays as indicators of nutrient limitation of phytoplankton in an eutrophic estuary. Mar Ecol Prog Ser 186:95-104

Howarth RW (1988) Nutrient limitation of net primary production in marine ecosystems. Annu Rev Ecol Syst 19: 89-110

Kerrison PD, Stanley MS, Edwards MD, Black KD, Hughes $\mathrm{AD}$ (2015) The cultivation of European kelp for bioenergy: site and species selection. Biomass Bioenergy 80: $229-242$

Kraan S (2013) Mass-cultivation of carbohydrate rich macroalgae, a possible solution for sustainable biofuel production. Mitig Adapt Strategies Glob Change 18:27-46

Krause-Jensen D, Markager S, Dalsgaard T (2012) Benthic and pelagic primary production in different nutrient regimes. Estuaries Coasts 35:527-545

Kronvang B, Jeppesen E, Conley DJ, Søndergaard M, Larsen SE, Ovesen NB, Carstensen J (2005) Nutrient pressures and ecological responses to nutrient loading reductions in Danish streams, lakes and coastal waters. J Hydrol (Amst) 304:274-288

Larsen MM (2013) Environmentally dangerous substances in sediment (NOVANA Technical Instruction for Marine Monitoring). M24. Danish Centre for Environment and Energy, Aarhus University

*Lyngby JE (1990) Monitoring of nutrient availability and limitation using the marine macroalgae Ceramium rubrum (Huds) G. Ag. Aquat Bot 38:153-161

KLyngby JE, Mortensen S, Ahrensberg N (1999) Bioassessment techniques for monitoring of eutrophication and nutrient limitation in coastal ecosystems. Mar Pollut Bull 39:212-223

*Maar M, Timmermann K, Petersen JK, Gustafsson KE, Storm LM (2010) A model study of the regulation of blue mussels by nutrient loadings and water column stability in a shallow estuary, the Limfjorden. J Sea Res 64: 322-333

KManns D, Deutschle AL, Saake B, Meyer AS (2014) Methodology for quantitative determination of the carbohydrate composition of brown seaweeds (Laminariaceae). RSC Advances 4:25736-25746

Marinho G, Holdt S, Birkeland M, Angelidaki I (2015a) Commercial cultivation and bioremediation potential of sugar kelp, Saccharina latissima, in Danish waters. J Appl Phycol 27:1963-1973

Marinho GS, Holdt SL, Angelidaki I (2015b) Seasonal variations in the amino acid profile and protein nutritional value of Saccharina latissima cultivated in a commercial IMTA system. J Appl Phycol 27:1991-2000

Markager SS (2004) Light extinction (NOVANA technical instruction for marine monitoring). Book 1.3. Danish Centre for Environment and Energy, Aarhus University

Markager SS, Fossing H (2013) Chlorophyll a concentration (NOVANA technical instruction for marine monitoring). Book M07. Danish Centre for Environment and Energy, Aarhus University 
Markager S, Storm LM, Stedmon CA (2006) Limfjordens miljøtilstand 1985 til 2003. Sammenhæng mellem næringsstoftilførsler, klima og hydrografi belyst ved empiriske modeller. Report 577 National Environmental Research Institute, Roskilde

Miyashita K, Nishikawa S, Beppu F, Tsukui T, Abe M, Hosokawa M (2011) The allenic carotenoid fucoxanthin, a novel marine nutraceutical from brown seaweeds. J Sci Food Agric 91:1166-1174

Nasrolahi A, Pansch C, Lenz M, Wahl M (2013) Temperature and salinity interactively impact early juvenile development: a bottleneck in barnacle ontogeny. Mar Biol 160: 1109-1117

Neori A, Chopin T, Troell M, Buschmann AH and others (2004) Integrated aquaculture: rationale, evolution and state of the art emphasizing seaweed biofiltration in modern mariculture. Aquaculture 231:361-391

Nielsen MM (2015) Cultivation of kelps for energy, fish feed and bioremediation. $\mathrm{PhD}$ thesis, Aarhus University

Nielsen MM, Bruhn A, Rasmussen MB, Olesen B, Larsen MM, Møller HB (2012) Cultivation of Ulva lactuca with manure for simultaneous bioremediation and biomass production. J Appl Phycol 24:449-458

Nielsen MM, Krause-Jensen D, Olesen B, Thinggaard R, Christensen P, Bruhn A (2014) Growth dynamics of Saccharina latissima (Laminariales, Phaeophyceae) in Aarhus Bay, Denmark, and along the species' distribution range. Mar Biol 161:2011

Nielsen MM, Manns D, D'Este M, Krause-Jensen D and others (2016) Variation in biochemical composition of Saccharina latissima and Laminaria digitata along an estuarine salinity gradient in inner Danish waters. Algal Res 13:235-245

Nordic Committee on Food Analysis (2003) Nitrogen. Determination in foods and feeds according to Kjeldahl, 4th edn. NMKL 6, NordVal International, DTU Food, Danish Technical University, Søbord

Pedersen MF, Borum J (1997) Nutrient control of estuarine macroalgae: growth strategy and the balance between nitrogen requirements and uptake. Mar Ecol Prog Ser 161:155-163

Pedersen B, Ærtebjerg G, Larsen MM (2004) Water chemistry parametres (NOVANA Technical Instruction for Marine Monitoring). Book 2.2. Danish Centre for Environment and Energy, Aarhus University

Pedersen MF, Borum J, Fotel FL (2010) Phosphorus dynamics and limitation of fast- and slow-growing temperate seaweeds in Oslofjord, Norway. Mar Ecol Prog Ser 399: 103-115

Peteiro C, Freire O (2009) Effect of outplanting time on commercial cultivation of kelp Laminaria saccharina at the southern limit in the Atlantic coast, NW Spain. Chin J Oceanology Limnol 27:54-60

Peteiro C, Freire O (2013a) Epiphytism on blades of the edible kelps Undaria pinnatifida and Saccharina latissima farmed under different abiotic conditions. J World Aquacult Soc 44:706-715

Peteiro C, Freire Ó (2013b) Biomass yield and morphological features of the seaweed Saccharina latissima cultivated at two different sites in a coastal bay in the Atlantic coast of Spain. J Appl Phycol 25:205-213

Petersen JK, Hasler B, Timmermann K, Nielsen P, Tørring DB, Larsen MM, Holmer M (2014) Mussels as a tool for mitigation of nutrients in the marine environment. Mar Pollut Bull 82:137-143
Rössner Y, Krost P (2012) Verfahrensentwicklung und Anlagenkonzeption für die extraktive Aquakultur von $\mathrm{Mu}-$ scheln und Makroalgen in der Ostsee (Extractive Baltic Aquaculture of Mussels and Algae EBAMA). Abschlussbericht für das Projekt EBAMA AZ 27119-34. Coastal Research \& Management, Kiel

* Sanderson JC, Dring MJ, Davidson K, Kelly MS (2012) Culture, yield and bioremediation potential of Palmaria palmata (Linnaeus) Weber \& Mohr and Saccharina latissima (Linnaeus) C.E. Lane, C. Mayes, Druehl \& G.W. Saunders adjacent to fish farm cages in northwest Scotland. Aquaculture 354-355:128-135

* Seghetta M, Tørring DB, Bruhn A, Thomsen M (2016) Bioextraction potential of macroalgae in Denmark - an instrument for circular nutrient management. Sci Total Environ 563-564:513-529

* Sharp GJ, Samant HS, Vaidya OC (1988) Selected metal levels of commercially valuable seaweeds adjacent to and distant from point sources of contamination in Nova Scotia and New Brunswick. Bull Environ Contam Toxicol 40:724-730

Smale DA, Burrows MT, Moore P, O'Connor N, Hawkins SJ (2013) Threats and knowledge gaps for ecosystem services provided by kelp forests: a northeast Atlantic perspective. Ecol Evol 3:4016-4038

Stephens D, Capuzzo E, Aldrigde J, Forster RM (2014) Potential interactions of seaweed farms with natural nutrient sinks in kelp beds. The Crown Estate, London

* Timmermann K, Dinesen GE, Markager S, Ravn-Jonsen L, Bassompierre M, Roth E, Støttrup JG (2014) Development and use of a bio-economic model for management of mussel fisheries under different nutrient regimes in the temperate estuary of the Limfjord, Denmark. Ecol Soc 19:14

* Troell M, Rönnbäck P, Halling C, Kautsky N, Buschmann A (1999) Ecological engineering in aquaculture: use of seaweeds for removing nutrients from intensive mariculture. J Appl Phycol 11:89-97

Vang T (2013) CTD measurement (NOVANA technical instruction for marine monitoring). Book M03. Danish Centre for Environment and Energy, Aarhus University

Vang T, Hansen JW (2013) Oxygen in the water column (NOVANA technical instruction for marine monitoring). Book M04. Danish Centre for Environment and Energy, Aarhus University

Wegeberg S (2010) Cultivation of kelp species in the Limfjord, Denmark. Department of Biology, SCIENCE, Copenhagen University

Wegeberg S, Mols-Mortensen A, Engell-Sørensen K (2013) Sustainable production and utilization of marine resources in the Arctic, fish and seaweed (SPUMA). Danish Centre for Environment and Energy rapport, Aarhus University

Wei N, Quarterman J, Jin YS (2013) Marine macroalgae: an untapped resource for producing fuels and chemicals. Trends Biotechnol 31:70-77

Werner A, Edwards M, Mineur F, O'Mahony F, Guiry M, Maggs C, Dring MJ (2009) Development of commercialscale seaweed aquaculture for selected species in Ireland. Phycologia 48(Suppl):141

Widdows J (1991) Physiological ecology of mussel larvae. Aquaculture 94:147-163

Wiles PJ, van Duren LA, Häse C, Larsen J, Simpson JH (2006) Stratification and mixing in the Limfjorden in relation to mussel culture. J Mar Syst 60:129-143 